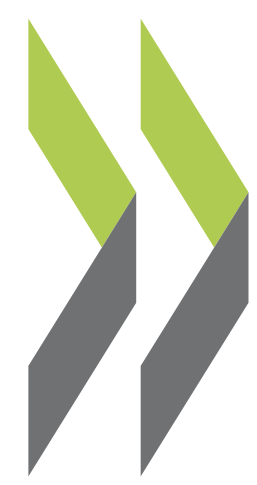

OECD Economics Department Working Papers No. 1348

Effects of FlexibilityEnhancing Reforms on Employment Transitions

\section{Boris Cournède,}

Oliver Denk,

Paula Garda 
Organisation de Coopération et de Développement Économiques

Organisation for Economic Co-operation and Development

28-Nov-2016

ECONOMICS DEPARTMENT

English - Or. English

\section{EFFECTS OF FLEXIBILITY-ENHANCING REFORMS ON EMPLOYMENT TRANSITIONS}

ECONOMICS DEPARTMENT WORKING PAPERS No. 1348

By Boris Cournède, Oliver Denk and Paula Garda

OECD Working Papers should not be reported as representing the official views of the OECD or of its member countries. The opinions expressed and arguments employed are those of the author(s).

Authorised for publication by Christian Kastrop, Director, Policy Studies Branch, Economics Department.

All Economics Department Working Papers are available at www.oecd.org/eco/workingpapers.

JT03406334

Complete document available on OLIS in its original format

This document and any map included herein are without prejudice to the status of or sovereignty over any territory, to the delimitation of international frontiers and boundaries and to the name of any territory, city or area. 
OECD Working Papers should not be reported as representing the official views of the OECD or of its member countries. The opinions expressed and arguments employed are those of the author(s).

Working Papers describe preliminary results or research in progress by the author(s) and are published to stimulate discussion on a broad range of issues on which the OECD works.

Comments on Working Papers are welcome, and may be sent to OECD Economics Department, 2 rue André Pascal, 75775 Paris Cedex 16, France, or by e-mail to eco.contact@oecd.org.

All Economics Department Working Papers are available at www.oecd.org/eco/workingpapers.

This paper is part of an OECD project on the consequences of flexibility-enhancing reforms for workers. Other outputs from this project include:

Cournède, B., O. Denk, P. Garda and P. Hoeller (2016), "Enhancing Economic Flexibility: What Is in It for Workers?", OECD Economic Policy Papers, No. 19, OECD Publishing (for an overview of the research and policy implications).

Denk, O. (2016), "How Do Product Market Regulations Affect Workers? Evidence from the Network Industries", OECD Economics Department Working Papers, No. 1349, OECD Publishing.

Garda, P. (2016), "The Ins and Outs of Employment in 25 OECD Countries", OECD Economics Department Working Papers, No. 1350, OECD Publishing.

This document and any map included herein are without prejudice to the status of or sovereignty over any territory, to the delimitation of international frontiers and boundaries and to the name of any territory, city or area.

Latvia was not an OECD Member at the time of preparation of this publication. Accordingly, Latvia does not appear in the list of OECD Members and is not included in the zone aggregates.

\section{(C) OECD (2016)}

You can copy, download or print OECD content for your own use, and you can include excerpts from OECD publications, databases and multimedia products in your own documents, presentations, blogs, websites and teaching materials, provided that suitable acknowledgment of OECD as source and copyright owner is given. All requests for commercial use and translation rights should be submitted to rights@oecd.org 
ECO/WKP(2016)72

\section{ABSTRACT/RÉSUMÉ}

\section{Effects of flexibility-enhancing reforms on employment transitions}

Do flexibility-enhancing reforms imply more employment instability? Using individual-level data from harmonised household surveys for 26 advanced countries, this paper analyses the effects of product and labour market reforms on transitions in and out of employment. Results indicate that reforms making product markets more competitive increase transitions out of employment for less qualified and lowincome workers. Less qualified and low-income workers have very high job exit rates to start with, and reforms raise these rates further. On the other hand, more pro-competitive product market regulation generally increases entry rates into employment. The concentration on less qualified and low-income workers of the increase in labour market turnover associated with product market reforms suggests a case for accompanying such reforms with labour market programmes that help the most vulnerable workers transition to new jobs. Easing employment protection for regular or temporary workers has no systematic long-term effect on workers' probabilities to move in or out of employment. Such reforms can, however, affect employment transitions through their interaction with other policies and institutions. For example, easing employment protection for workers with regular contracts raises the job-finding chances of people out of work in countries that invest a lot in active labour market programmes. Furthermore, employment protection legislation and product market regulation are complementary in that, when either employment protection or product markets are lightly regulated, reforming the other is associated with fewer job exits.

JEL Classification: D04; J08; J63

Keywords: labour market, structural reform, employment protection legislation, product market regulation, micro data

$$
\text { ***** } *
$$

\section{Les mesures de flexibilité et leurs effets sur les transitions professionnelles}

Les réformes visant à accroître la flexibilité des marchés sont-elles porteuses d'instabilité en matière d'emploi ? À l'aide de données individuelles tirées d'enquêtes harmonisées menées auprès des ménages dans 26 pays avancés, cet article analyse les effets que peuvent avoir les réformes du marché du travail et du marché des produits sur les transitions professionnelles. Les résultats montrent que les réformes qui améliorent la compétitivité des marchés de produits augmentent les pertes d'emploi parmi les travailleurs peu qualifiés et à bas salaire, dont les taux de sortie, déjà élevés au départ, le sont encore plus à l'arrivée. D'un autre côté, une réglementation plus favorable à la concurrence sur les marchés de produits se traduit généralement par une hausses des taux d'accès à l'emploi. La concentration sur certaines catégories de travailleurs, en l'occurrence les moins qualifiés et les moins bien rémunérés, de l'augmentation du taux de rotation de la main-d'œuvre associé aux réformes des marchés de produits plaide en faveur de la mise en place, en complément de ces réformes, de programmes du marché du travail visant à faciliter le retour à l'emploi des travailleurs les plus vulnérables. L'assouplissement des mesures de protection de l'emploi permanent ou temporaire n'a pas d'effet systématique à long terme sur la probabilité de passer du chômage à l'emploi ou inversement. Ce type de réforme peut toutefois avoir une incidence sur les transitions professionnelles de par ses interactions avec d'autres politiques et institutions. On s'aperçoit ainsi qu'une protection moins stricte des contrats à durée indéterminée augmente les chances de trouver un emploi dans les pays où les programmes actifs du marché du travail sont très développés. De plus, la complémentarité de la législation sur la protection de l'emploi et de la réglementation des marchés de produits fait que l'assouplissement de l'une permet de réformer l'autre en réduisant les pertes d'emploi.

Classfication JEL : D04 ; J08 ; J63

Mots-cés : marché du travail, réforme structurelle, législation sur la protection de l'emploi, réglementation du marché des produits, microdonnées 


\section{TABLE OF CONTENTS}

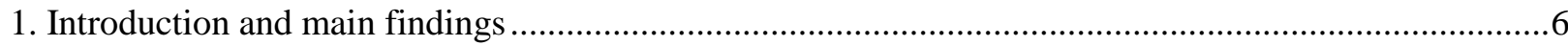

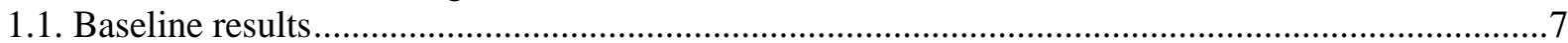

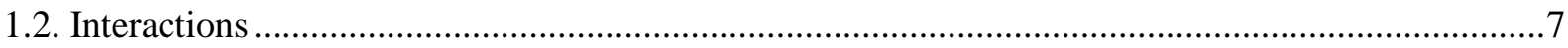

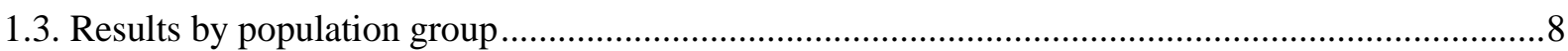

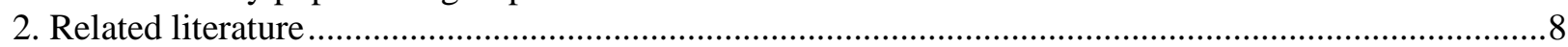

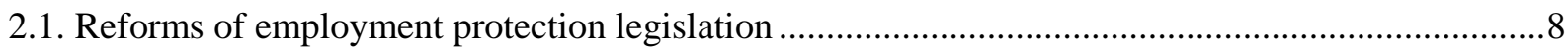

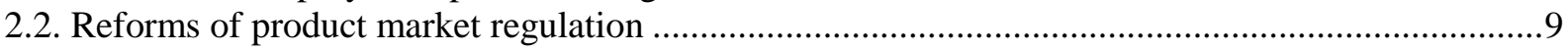

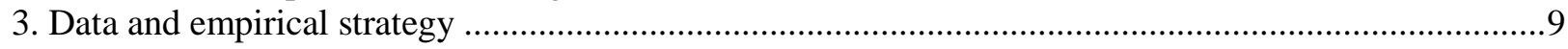

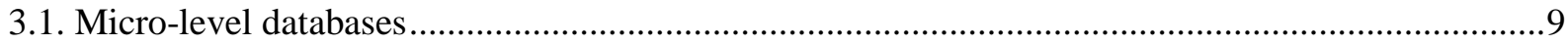

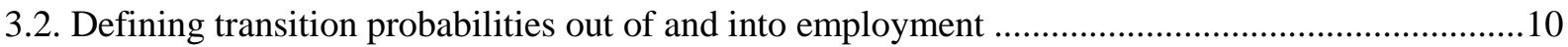

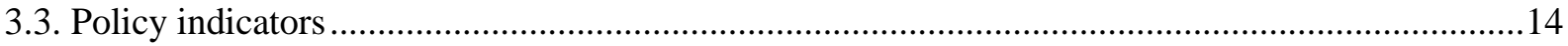

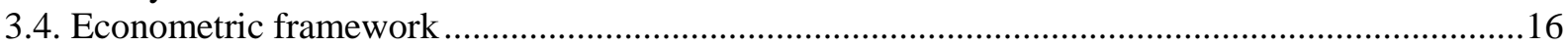

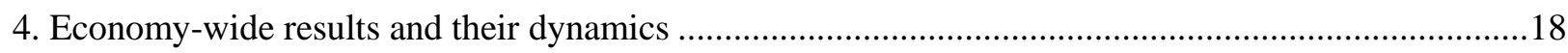

4.1. Long-term relationships between more flexible policies and transitions in and out

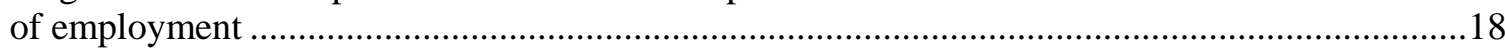

4.2. Decomposing joblessness into unemployment and economic inactivity ....................................21

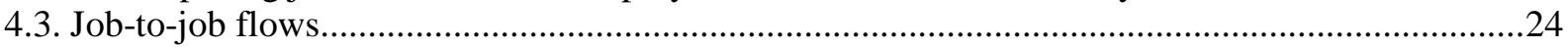

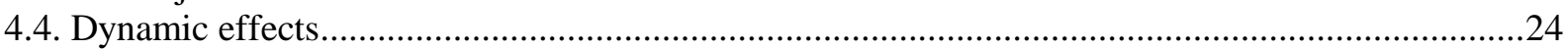

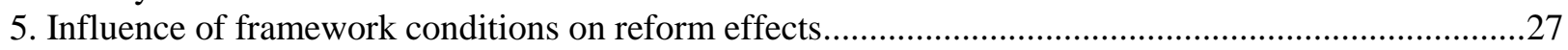

5.1. Active labour market policies and the chances of becoming employed..........................................27

5.2. Coordination of wage bargaining and the chances of becoming employed ....................................30

5.3. Coordination of wage bargaining and the chances of becoming jobless ..........................................

5.4. The interaction of flexible labour and product markets and the chances of becoming jobless ........31

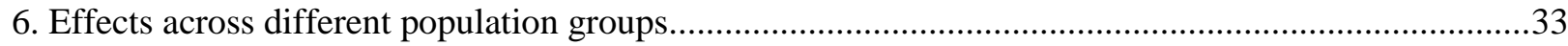

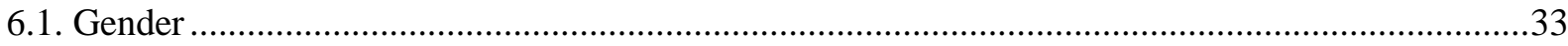

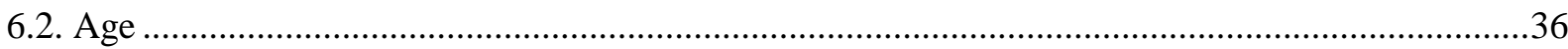

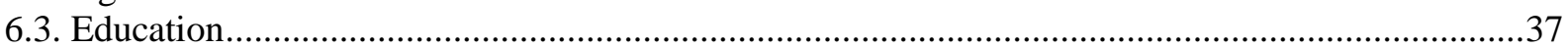

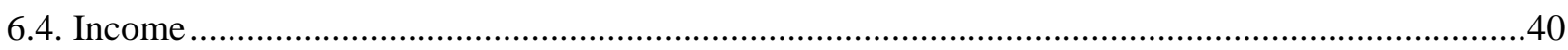

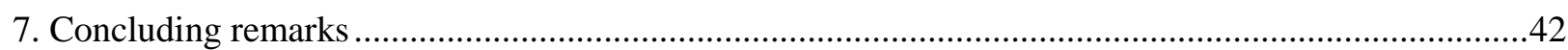

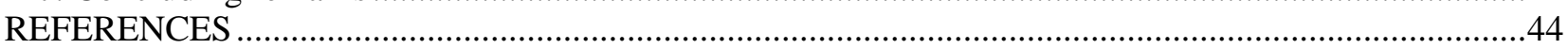

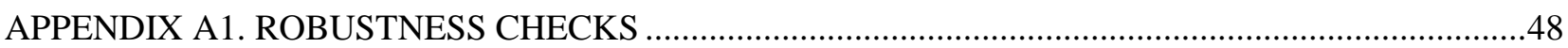

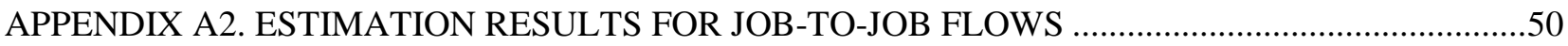

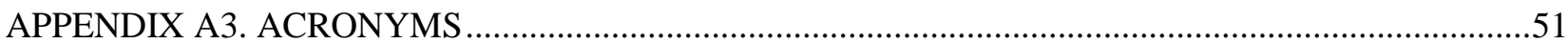

\section{Tables}

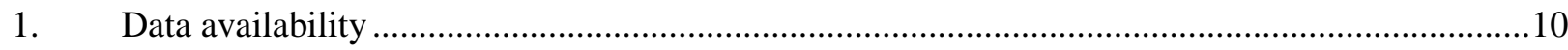

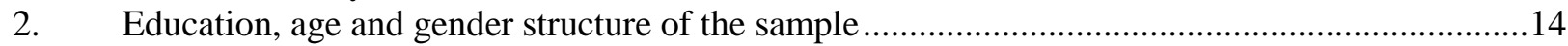

3. Typical labour and product market reforms in OECD countries .................................................16

4. Estimated effects of employment protection and product market regulation

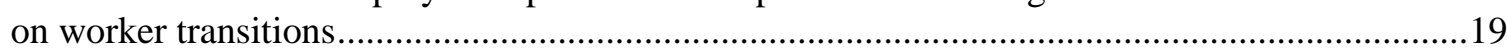


5. Estimated effects of flexibility-enhancing reforms on transition rates into and out of unemployment and economic inactivity

6. Complementarity between employment protection reforms and ALMP spending

for new hirings .....

7. Estimated effects of more flexible product and labour market regulation ....................................43

A1.1. Adding other policy variables to the baseline estimation .........................................................49

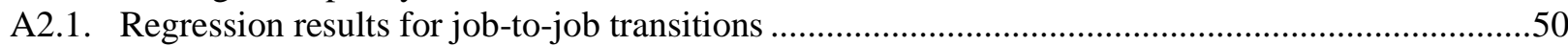

\section{Figures}

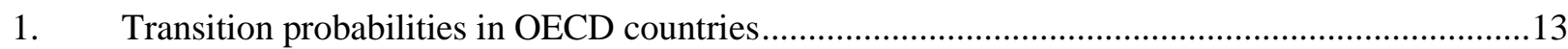

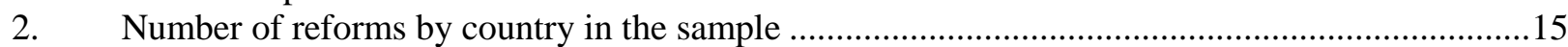

3. The impact of typical flexibility-enhancing reforms on transition probabilities...........................20

4. Estimated effects of flexibility-enhancing reforms on transition probabilities into and out

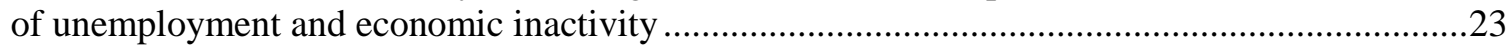

5. Estimated dynamic economy-wide effects of ETCR deregulation ............................................25

6. Estimated dynamic effects of easing job protection for regular contracts ...................................26

7. Estimated dynamic effects of easing job protection for temporary contracts ..............................27

8. The positive effect of activation programmes on the hiring benefits from employment protection reforms

9. The positive effect of more decentralised wage bargaining on the hiring benefits

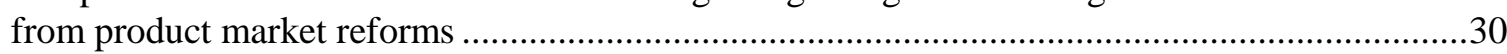

10. Effect of more flexible EPL for regular contracts on the probability of becoming jobless

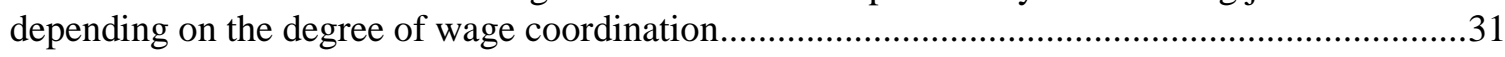

11. Effect of a typical ETCR reform on the probability of becoming jobless depending

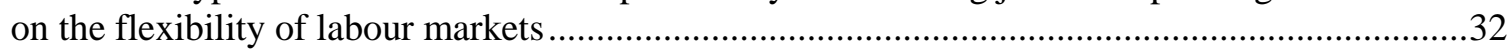

12. Effect of typical flexibility-enhancing reforms on job-finding chances for men and women ........34

13. Effect of typical flexibility-enhancing reforms on the risk of becoming jobless

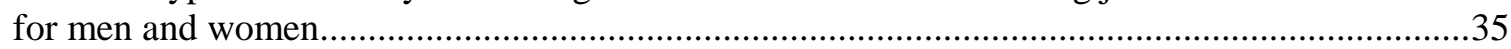

14. Effect of a typical product market reform on job-finding chances by age ..................................36

15. Effect of a typical product market reform on the chance of finding a job by skill level................37

16. Effect of a typical product market reform on the risk of becoming jobless by skill level .............38

17. Implied employment rate effects of product market reforms ....................................................39

18. Effect of a typical product market reform on the chance of finding a job by income level...........40

19. Effect of a typical product market reform on the risk of becoming jobless by income level ........41

\section{Box}

Box 1. Definition of average transition probabilities and their link with changes in employment rates 


\title{
EFFECTS OF FLEXIBILITY-ENHANCING REFORMS ON EMPLOYMENT TRANSITIONS
}

\author{
By Boris Cournède, Oliver Denk and Paula Garda ${ }^{1}$
}

\section{Introduction and main findings}

1. Flexibility-enhancing economic reforms generally raise growth and productivity, but do they come at the cost of higher employment instability? This paper analyses how reforms that make labour or product markets more flexible influence the risks for workers to lose a job and the chances for people who do not work to get a job. It therefore contributes to a better understanding of how flexibility-enhancing reforms affect labour market outcomes that not only have important monetary consequences but also strongly influence well-being. Economic literature underlines the strong negative impacts of becoming unemployed on well-being (Clark and Oswald, 1994; Frey and Stutzer, 2000). Recent OECD work finds that the subjective cost of being unemployed is equivalent to $95 \%$ of an individual's annual income (Boarini et al., 2012).

2. This paper uses worker-level data covering 26 OECD countries to study how labour and product market policies influence transitions from employment to joblessness and from joblessness to employment. The paper defines working-age people as jobless when they are unemployed or economically inactive (i.e. out of the labour force). The richness of the underlying data, which are drawn from monthly information, allows a quantitatively detailed characterisation of labour market transitions. The analysis focuses mostly on long-term effects but also investigates dynamic paths towards long-term effects.

3. The paper focuses on reforms that instil greater flexibility in product market regulation (PMR) or employment protection legislation (EPL). It also looks at the extent to which other policies and framework conditions in the areas of active labour market policies and collective bargaining influence the impact of PMR and EPL reforms. In addition, it analyses how the effects on individual workers' transitions depend on their characteristics, in particular gender, age, education and income. This paper is the first systematic investigation into the effects of PMR and EPL reforms, framework conditions and worker heterogeneity for employment stability within a coherent framework using a database gathering micro-data for 26 OECD countries that were harmonised for this purpose. ${ }^{2}$

1. The authors are economists in the OECD Economics Department. Emails: Boris.Cournede@oecd.org, Oliver.Denk@oecd.org and Paula.Garda@oecd.org. Earlier versions of this paper were discussed by the Working Party No. 1 on Macroeconomic and Structural Policy Analysis of the Economic Policy Committee, the Working Party on Employment of the Employment, Labour and Social Affairs Committee and the network of National Economic Research Organisations. The authors would like to thank the participants for their feedback. They are indebted to Economics Department colleagues Peter Hoeller, Christian Kastrop, Catherine Mann and Jean-Luc Schneider for supervising and guiding the project and to Jon Pareliussen and Urban Sila for their reviews of the research. They are also grateful to the following for valuable comments and suggestions: Andrea Bassanini, Federico Cingano, Mark Keese (Directorate for Employment, Labour and Social Affairs); Alberto González Pandiella, Vincent Koen, Jae Wan Lee (Economics Department); Lamia Kamal-Chaoui (Centre for Entrepreuneurship, SMEs and Local Development); and Fabrice Murtin (Statistics Directorate). Special thanks go to former Economics Department members Noémie Pinardon-Touati and Flora Vourch for excellent research assistance and to Celia Rutkoski for outstanding editorial assistance.

2. A complementary OECD project analyses reform effects on income distribution with country-level data (Causa et al., 2016). The micro-level databases harmonised for this study are best suited to investigating labour-market transitions, as their richness allows a detailed characterisation of moves into and out of employment. Compared with the micro-level databases, the country-level statistics on income by decile 
4. The main findings are as follows.

\subsection{Baseline results}

- In the long term:

- For a person out of employment, more flexible product market regulation means a higher chance of becoming employed. This effect of greater product market competition results from more frequent transitions into employment from inactivity rather than from unemployment. A possible explanatory channel is that, by reducing mark-ups, more pro-competitive regulation can boost productivity and wages, bringing into the labour force people who were marginally attached to it.

- More flexible product market regulation has no significant effect on the risk of becoming jobless.

- The positive effect of reduced product market regulation on job finding chances and its lack of significant effect on the risk of becoming jobless would imply that such reforms raise the long-term employment rate, in line with aggregate evidence (Gal and Theising, 2015).

- In the short to medium term, reforms that make network industry regulation more flexible are followed by:

- an immediate, though only weakly statistically significant, increase in the risk of becoming jobless, which vanishes one to two years after the reform;

- a gradual rise in the chance of getting a job, which becomes economically large three to four years after the reform.

\subsection{Interactions}

- In countries with above-average spending on active labour market programmes, easing dismissal rules increases job finding chances for individuals who are out of work. The identified positive interaction between active labour market policies and weak dismissal regulation for job-finding chances seems to come primarily from public employment services rather than training.

- The positive effect of product market reforms on the chances of becoming employed is larger at low levels of coordination in wage bargaining. This interaction may reflect that decentralised arrangements better align wages with productivity, which product market reforms boost.

- More flexible employment protection for regular contracts is linked with a higher probability of becoming jobless when coordination in wage bargaining takes on intermediate levels. This link suggests that in countries with intermediate wage coordination and low employment protection firms may be more likely to reduce costs by laying off workers rather than adjusting wages.

- Employment protection legislation and product market regulation are complementary in that, when either employment protection or product markets are lightly regulated, reforming the other is associated with fewer job exits.

used in Causa et al. (2016) cover longer time periods and more countries, which makes them a better fit to analyse distributional effects of reforms on income. 


\subsection{Results by population group}

- The average positive effects of product market reforms on job-findings rate stem primarily from stronger beneficial effects for women and young workers. They apply, by and large, uniformly across different education and income groups.

- Product market reforms exert no influence on the average risk of becoming jobless. However, this lack of aggregate effect conceals heterogeneous impacts across population groups. Product market reforms increase the risk of becoming jobless for individuals with low education or low income and hence for social groups who already have the highest likelihood to become jobless.

- Labour market reforms, which have no discernible aggregate effect on transition rates, exhibit no systematic relationship with the probability of becoming employed or jobless across groups.

5. The rest of the document briefly surveys the related economic literature in the next section (2), before presenting the data and the transition variables created for the analysis (Section 3). The following section (4) describes the methodology and results of estimating average effects on individuals across the economy, including how they build up over time and a discussion of how they relate to existing evidence on the employment effects of reforms. Section 5 analyses the influence of framework conditions. Section 6 investigates how effects vary across different individuals depending on their characteristics. The paper concludes with summary remarks and possible avenues for future research (Section 7). Appendices A1 and A2 present regression results for respectively robustness checks and job-to-job flows. Appendix A3 spells out acronyms used throughout the paper.

\section{Related literature}

6. This section provides a selective survey of the literature studying the impact of labour and product market reforms on transitions into and out of employment. It focuses on empirical papers and especially studies with a cross-country dimension. It draws on a specially commissioned review of the literature (Boeri et al., 2015). More extensive literature reviews can be found in OECD $(2010,2013)$.

\subsection{Reforms of employment protection legislation}

7. The theoretical literature expects reforms that relax employment protection legislation for regular contracts to facilitate firing and encourage hiring, because they lower the expected cost of future lay-offs. Empirical studies have generally found increased lay-off rates, after EPL reforms were implemented (Boeri and Jimeno, 2005; Marinescu, 2009; von Below and Thoursie, 2010). On the other hand, positive effects on hiring rates have been found to materialise more slowly, as employers gradually incorporate the lower expected cost of job termination in their recruitment decisions (Behagel et al., 2008). In the long term, more flexible employment protection has been found to be associated with more hiring and firing and greater job reallocation within and across sectors (Gomez Salvador et al., 2004; Jackman et al., 1996; Micco and Pagés, 2006; Bassanini and Garnero, 2013; Murtin and de Serres 2014).

8. Little empirical evidence is available regarding the effects of easing EPL for temporary contracts on transitions in and out of employment. Reforms reducing employment protection for temporary contracts are generally seen as having an immediate positive effect on firm-level hirings and overall employment (Boeri and Garibaldi, 2007). Such reforms widen the gap between the expected costs of dismissing temporary and regular workers. Consequently, firms gradually replace permanent with temporary workers, a substitution that results in larger lay-off rates in downturns (Bentolila and Dolado, 1994). 


\subsection{Reforms of product market regulation}

9. Reforms that make product markets more competitive have been found to boost productivity in part through job reallocations and staff cuts, implying higher rates of labour market transitions (Olley and Pakes, 1996; Disney et al., 2003). More competitive markets also lead to lower cost-price margins, which have been found to translate into lower job security (Aparicio-Fenoll, 2015). Empirical studies have generally found that product market reforms boost employment in the long term (Alesina et al., 2005; Schiantarelli, 2010; Gal and Theising, 2015; OECD, 2016).

\section{Data and empirical strategy}

\subsection{Micro-level databases}

10. Longitudinal/panel household surveys provide a rich basis for studying individual labour market outcomes. This paper draws on five different household surveys to build a database harmonising microlevel data across 26 OECD countries.

11. Two micro panels provide information on individual characteristics, labour market participation and earnings across European countries:

- The European Community Household Panel (ECHP) covers 15 European OECD countries from 1994 to 2001. The ECHP follows individuals over time.

- The European Union Statistics on Income and Living Conditions (EU-SILC) survey covers 24 European OECD countries from 2003 to 2013. Participants rotate quickly in EU-SILC: Individuals are replaced within four years in most countries.

12. These panels are complemented with household surveys for three OECD countries: Australia (HILDA, 2001-12), Germany (SOEP, 1994-2012) and Switzerland (SHP, 1999-2013). For Germany, the study uses the national SOEP survey, instead of ECHP and EU-SILC, because SOEP covers a longer period and follows individuals for longer. Canada's Survey of Labour and Income Dynamics (SLID) contains suitable information for the analysis in this paper. However, this analysis could not use it, because the SLID micro-data cannot be pooled with the other datasets, as is needed for the regressions employed herein.

13. The final dataset represents a large panel of workers aged between 25 and 59 years across 26 OECD countries (Table 1). The sample is restricted to people aged 25 to 59 to mitigate possible distortions to the estimations through youth who take up work or workers who retire. The econometric analysis covers the 1994-2012 period to have a more balanced panel.

14. The final dataset has strengths and weaknesses. An important strength is that it provides monthly information about whether people are working, unemployed or economically inactive. This high frequency allows observing labour market transitions in and out of employment at a high level of detail, including for people who alternate between precarious jobs, unemployment and economic inactivity. Another Source of strength is that the dataset contains individual-level information about labour income, which makes it possible to look at differences in outcomes depending on where workers are located in the earnings distribution. By contrast, a weakness of the dataset is that it comprises substantially fewer observations than labour force surveys. The present dataset has nevertheless been preferred since harmonised labour force surveys observe employment status only at quarterly frequency and do not report income information before 2009 . 
Table 1. Data availability

\begin{tabular}{|c|c|c|c|c|c|c|c|c|c|c|c|c|c|c|c|c|c|}
\hline & 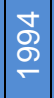 & $\left|\begin{array}{l}10 \\
8 \\
\circ \\
\end{array}\right|$ & \begin{tabular}{l|l}
0 & 1 \\
$o$ & 1 \\
$o$ & 1 \\
& 1
\end{tabular} & \begin{tabular}{l|l}
$\hat{\sigma}$ & \\
के & \\
&
\end{tabular} & \begin{tabular}{l|l}
$\infty$ & న \\
o & م \\
क & क \\
\end{tabular} & 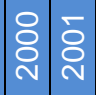 & $\begin{array}{l}\text { 이 } \\
\text { 이 }\end{array}$ & $\mid$\begin{tabular}{l}
3 \\
8 \\
\hdashline \\
\hdashline
\end{tabular} & \begin{tabular}{l|l} 
& 1 \\
○ & $\mathfrak{c}$ \\
त & c
\end{tabular} & \begin{tabular}{l|l}
10 & $\mathfrak{c}$ \\
8 & $\mathfrak{c}$ \\
$\varnothing$ & $\mathfrak{c}$
\end{tabular} & \begin{tabular}{l|l}
0 & 1 \\
8 & $c$ \\
$\odot$ & $c$ \\
\hdashline & $c$
\end{tabular} & 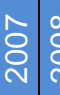 & 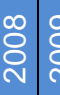 & 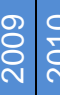 & 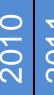 & T⿳亠丷厂 & $\frac{N}{\circ}$ \\
\hline AUS & & & & & & & & & & & & & & & & & \\
\hline AUT & & & & & & & & & & & & & & & & & \\
\hline BEL & & & & & & & & & & & & & & & & & \\
\hline $\mathrm{CHE}$ & & & & & & & & & & & & & & & & & \\
\hline CZE & & & & & & & & & & & & & & & & & \\
\hline DEU & & & & & & & & & & & & & & & & & \\
\hline DNK & & & & & & & & & & & & & & & & & \\
\hline ESP & & & & & & & & & & & & & & & & & \\
\hline EST & & & & & & & & & & & & & & & & & \\
\hline FIN & & & & & & & & & & & & & & & & & \\
\hline FRA & & & & & & & & & & & & & & & & & \\
\hline GBR & & & & & & & & & & & & & & & & & \\
\hline GRC & & & & & & & & & & & & & & & & & \\
\hline HUN & & & & & & & & & & & & & & & & & \\
\hline $\mathrm{IRL}$ & & & & & & & & & & & & & & & & & \\
\hline ISL & & & & & & & & & & & & & & & & & \\
\hline ITA & & & & & & & & & & & & & & & & & \\
\hline LUX & & & & & & & & & & & & & & & & & \\
\hline NLD & & & & & & & & & & & & & & & & & \\
\hline NOR & & & & & & & & & & & & & & & & & \\
\hline $\mathrm{POL}$ & & & & & & & & & & & & & & & & & \\
\hline PRT & & & & & & & & & & & & & & & & & \\
\hline SVK & & & & & & & & & & & & & & & & & \\
\hline SVN & & & & & & & & & & & & & & & & & \\
\hline SWE & & & & & & & & & & & & & & & & & \\
\hline TUR & & & & & & & & & & & & & & & & & \\
\hline
\end{tabular}

Note: A shaded cell indicates that the dataset includes this country and year. Indicated years correspond to the income reference period in the source surveys.

Source: Authors' calculations using the European Community Household Panel (http://bit.ly/2gjPZ10), EU Survey of Income and Living Conditions (http://bit.ly/2flqXWd), the British Household Panel Survey (https://www.iser.essex.ac.uk/bhps), the Survey of Household, Income and Labour Dynamics in Australia (https://www.melbourneinstitute.com/hilda/), the Swiss Household Panel and the German Socio-Economic Panel (https://www.diw.de/en/soep).

\subsection{Defining transition probabilities out of and into employment}

15. The study focuses on transitions out of and into employment. ${ }^{3}$ The other possible state, referred to as joblessness, includes unemployment and economic inactivity. The framework used here allows studying transitions out of and into unemployment and economic inactivity.

16. The transition variables are built to meet two objectives. The main purpose of the transition variables is to measure employed workers' risk of becoming jobless and jobless people's chances of getting a job. The second goal is to allow linking changes in transition probabilities to changes in aggregate employment, as a way of relating the findings from this study to recent complementary OECD work that

3. For job-to-job flows, see Subsection 4.3 and OECD (2010, 2016), Bassanini et al. (2010) and Bassanini and Garnero (2013). 
re-evaluates the impact of structural policies on employment in the short (OECD, 2016) and long term (Gal and Theising, 2015).

\section{Transitions at the individual level}

17. Transitions $f_{t}^{E L}$ and $f_{t}^{L E}$ between employment $\mathrm{E}$ and joblessness $\mathrm{L}$ are defined as follows for individual worker $i$ over the course of year $t$ :

$$
f_{i t}^{E L}=\sum_{m=1}^{12} \delta_{i}^{E L}(m-1, m) \text { and } f_{i t}^{L E}=\sum_{m=1}^{12} \delta_{i}^{L E}(m-1, m),
$$

where $\delta_{i}^{E L}(m-1, m)$ is a dummy variable equal to 1 if individual $i$ is employed in month $m-1$ and jobless in month $m$. Dummy variable $\delta_{i}^{L E}(m-1, m)$ follows a symmetric definition for transitions from joblessness to employment.

18. Variable $f_{t}^{E L}$ therefore counts the number of transitions into joblessness that a worker employed at the end of year $t-1$ experiences. By using monthly information and summing transitions over the course of the year, this definition captures the experience of people who undergo precarious employment spells in a detailed manner. Symmetrically, $f_{t}^{L E}$ measures transitions into employment. Averaging variables $f_{t}^{E L}$ and $f_{t}^{L E}$ over all individuals yields generalised transition probabilities $\lambda_{t}^{E L}$ and $\lambda_{t}^{L E}$, which respectively measure the risk of becoming jobless and the chances of getting a job (Equation 3 in Box 1). These generalised transition probabilities offer the benefit of allowing to draw implications for employment rates (Box 1).

\section{Box 1. Definition of average transition probabilities and their link with changes in employment rates}

Transitions defined as in Equation 1 are closely linked with changes in aggregate employment $\left(E_{t}\right.$ at the end of year $t$ ). Aggregate employment changes as a result of transitions but also of moves into and out of the working-age population due to age, migration and death (and panel rotation when considering the sample rather than the whole country). An intermediate variable $E_{t}^{t-1, t}$ is used to distinguish between the effects of transitions and demography (and panel rotation in the sample). Variable $E_{t}^{t-1, t}$ counts how many people are employed at the end of year $t$, among those who were already present in the working-age population or sample at the end of year $t-1$. For convenience, the text below calls working-age people who stay in the sample from the end of year $t-1$ to the end of year $t$ "stayers" and places the superscript $t-1, t$ on variables that are restricted to them. Accordingly, variable $L_{t}^{t-1, t}$ counts stayers who are jobless (meaning not in employment) at the end of year $t$ and $E_{t-1}^{t-1, t}$ stayers who are employed at the end of year $t-1$. With these definitions, employment among stayers changes as people move in and out of work:

$$
E_{t}^{t-1, t}=E_{t-1}^{t-1, t}+\sum_{i} \sum_{m=1}^{12}\left[\delta_{i}^{L E}(m-1, m)-\delta_{i}^{E L}(m-1, m)\right],
$$

which simplifies to

$$
E_{t}^{t-1, t}=E_{t-1}^{t-1, t}+\sum_{i}\left(f_{i t}^{L E}-f_{i t}^{E L}\right) .
$$

Defining all variables using people who stay from the end of the previous year to the end of the current one offers the benefit of making the variables robust to changes in sample size. This consideration is very important given that the EU-SILC panel, which is the largest component of the present dataset, involves very fast rotation and often significant changes in sample size from one year to the next.

Individual indicator transition variables $f_{i t}^{L E}$ and $f_{i t}^{E L}$ can be aggregated among stayers into generalised transition probabilities from employment to joblessness $\lambda_{t}^{E L}$ and the other way around $\lambda_{t}^{E L}$ :

$$
\lambda_{t}^{E L}=\frac{\sum_{i} f_{i t}^{E L}}{E_{t-1}^{t-1, t}} \text { and } \lambda_{t}^{L E}=\frac{\sum_{i} f_{i t}^{L E}}{L_{t-1}^{t-1, t}}
$$




\section{Box 1. Definition of average transition probabilities and their link with changes in employment rates (cont.)}

These transition probabilities are generalised probabilities, since they could take a maximum value of six, if everybody in the working-age population hopped in and out of employment month after month. The name probability has been kept, because at monthly frequency they correspond to probabilities. The econometric analysis, however, cannot be directly conducted at monthly frequency, because all other variables than employment status are unavailable at this frequency. Furthermore, many people experience no or very few transitions, so that $\lambda_{t}^{E L}$ and $\lambda_{t}^{L E}$ usually remain well below unity.

An advantage of using this generalised definition of transition probabilities is that they allow calculating their implications for employment. Transition probabilities cannot be related to employment when they are defined using individual-level monthly data taking values of one even when workers experience multiple transitions within a year. Under the generalised definition of transition probabilities, employment follows Equation 4, which results from inserting (3) into (2):

$$
E_{t}^{t-1, t}-E_{t-1}^{t-1, t}=\lambda_{t}^{L E} L_{t-1}^{t-1, t}-\lambda_{t}^{E L} E_{t-1}^{t-1, t}
$$

This relationship can be rewritten in terms of the employment rate. This rate $e_{t}$ is defined as a ratio to $W_{t}^{t-1, t}$, the number of people who belong to the working-age population from the end of year $t-1$ to the end of $t$. The definition of $W_{t}^{t-1, t}$ means that it is equal to the number $W_{t-1}^{t-1, t}$ of people who are in the working-age population from the end of year $t-1$ to the end of $t$. Consequently, dividing (4) by $W_{t}^{t-1, t}$ and simplifying yields the following equation relating the evolution of the employment rate to transition probabilities:

$$
\frac{e_{t}-e_{t-1}}{e_{t-1}}=\lambda_{t}^{L E} \frac{1-e_{t-1}}{e_{t-1}}-\lambda_{t}^{E L} \text {. }
$$

A steady-state interpretation of this relationship provides an alternative way of gauging the employment effects of changes in transition probabilities. The steady-state employment rate $\hat{e}_{t}$ associated with flows $\lambda_{t}^{L E}$ and $\lambda_{t}^{E L}$ is defined as the employment rate that would prevail if the flows $\lambda_{t}^{L E}$ and $\lambda_{t}^{E L}$ remained constant. The steady-state employment rate can be calculated by using $\hat{e}_{t-1}=\hat{e}_{t}$ in (5). Solving the resulting equation for $\hat{e}$ yields:

$$
\hat{e}=\frac{\lambda^{L E}}{\lambda^{L E}+\lambda^{E L}} \text {. }
$$

Comparisons indicate that the implied steady-state employment rates $\hat{e}$ lie very close to, and evolve in sync with, actual employment rates in the sample (Garda, 2016). Any identified policy effects on transition probabilities $\lambda^{L E}$ and $\lambda^{E L}$ imply the following change in the steady-state employment rate, which is obtained by differentiating (6):

$$
\Delta \hat{e}=\frac{\frac{\lambda^{E L}}{\lambda^{L E}}}{\left(1+\frac{\lambda^{E L}}{\lambda^{L E}}\right)^{2}}\left(\frac{\Delta \lambda^{L E}}{\lambda^{L E}}-\frac{\Delta \lambda^{E L}}{\lambda^{E L}}\right) .
$$

The right-hand side of Equation 7 indicates that employment evolves with the same sign as the difference between the percentage changes of the transition probabilities for job entry and exit $\lambda^{L E}$ and $\lambda^{E L}$. The change in the steady-state employment rate does not, in contrast to the change in the actual employment rate, depend on the level of employment.

Transition probabilities and employment rates are all defined among people who stay in the population from one year to the next. The employment rates $e_{t}$ and $\hat{e}$ therefore approximate but are not strictly equal to their standard definitions, which use the total working-age population. Thus, (5) and (7) imperfectly measure changes in employment rates. A difference can open with the true change in the employment rate when two conditions are met at the same time: i) the working-age population changes, and ii) people entering or exiting the working-age population have a systematically different employment status from the stayers. The impact is likely to be small because the two conditions only have a multiplicative impact and the pace of demographic change is relatively subdued from one year to the next. ${ }^{1}$

1. Using Equation 5 or 7 to assess the employment rate implications of estimated policy effects on transition probabilities may only miss effects that specifically arise by changing the employment outcomes of people who enter or exit the working-age population. However, because these effects occur only through their difference with average outcomes and after multiplying them by the share of entries and exits in the working-age population, any such errors are likely to be small.

\section{Descriptive statistics}

19. Transition probabilities calculated by applying the definitions of $\lambda_{t}^{E L}$ and $\lambda_{t}^{L E}$ at the country level show the diversity of OECD labour markets (Figure 1). Every year, many workers in countries such as 
Austria, Finland, Portugal, Spain and Sweden move from employment to unemployment or inactivity and vice versa. On the other hand, all forms of labour market transitions reported in Figure 1 are relatively infrequent in Belgium, the Czech Republic, France, Luxembourg, Poland, the Slovak Republic and Slovenia.

Figure 1. Transition probabilities in OECD countries

A. Transition probabilities employment-joblessness: $\lambda^{E L}$

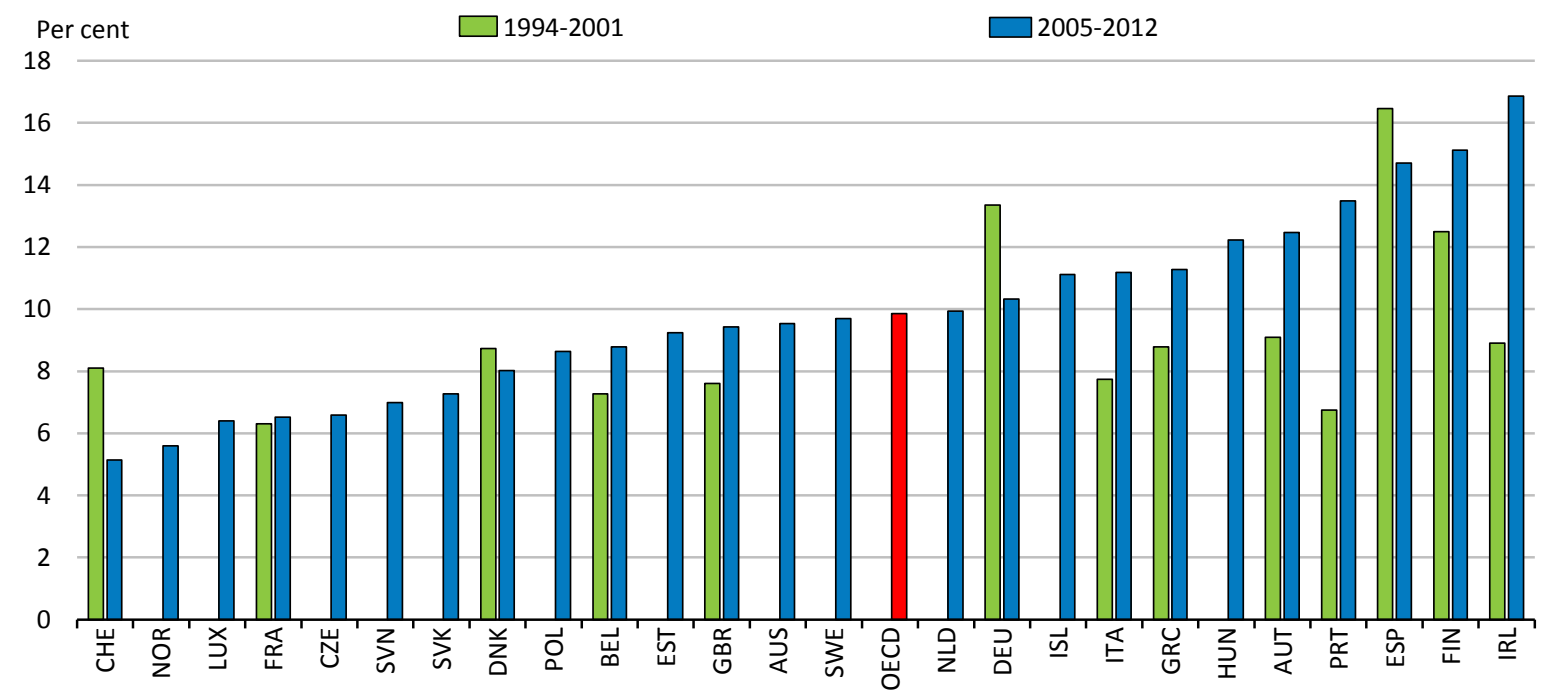

B. Transition probabilities joblessness-employment: $\lambda^{L E}$

Per cent $\quad \square$ 1994-2001 $\quad \square$ 2005-2012
$70 \longrightarrow$

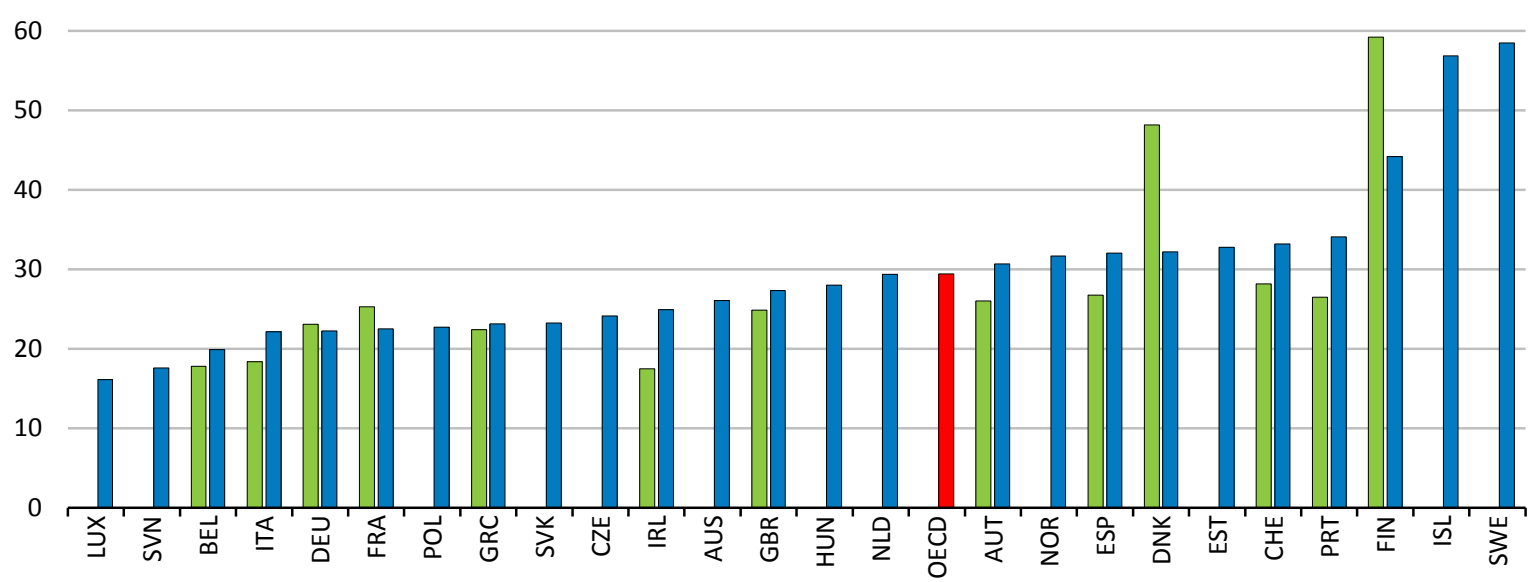

Note: The figure reports averages from weighted samples for the periods 1994-2001 and 2005-12 (or the last year available). OECD is the simple average across the countries shown in the figure.

Source: Authors' calculations using the European Community Household Panel (http://bit.ly/2gjPZ10), the EU Survey of Income and Living Conditions (http://bit.ly/2flqXWd), the British Household Panel Survey (https://www.iser.essex.ac.uk/bhps), the Survey of Household, Income and Labour Dynamics in Australia (https://www.melbourneinstitute.com/hilda/), the Swiss Household Panel and the German Socio-Economic Panel (https://www.diw.de/en/soep). 
20. An important part of the empirical analysis explores the heterogeneity of reform impacts depending on worker characteristics. Table 2 shows summary statistics for the highest level of education achieved, age and gender.

Table 2. Education, age and gender structure of the sample

\begin{tabular}{|c|c|c|}
\hline \multicolumn{3}{|c|}{ Percentages } \\
\hline & & OECD \\
\hline \multicolumn{2}{|c|}{ Less than High School } & 22 \\
\hline \multicolumn{2}{|c|}{ High School } & 48 \\
\hline \multicolumn{2}{|c|}{ More than High School } & 30 \\
\hline \multirow[t]{3}{*}{ Age } & $>=25,<=35$ & 30 \\
\hline & $>=36,<=45$ & 30 \\
\hline & $>=46,<60$ & 40 \\
\hline Male & & 49 \\
\hline
\end{tabular}

Note: The table reports averages for the period 2004-12 (or the last year available). OECD is the simple average across the 26 countries in the sample. The statistics are calculated on micro-level datasets from EU-SILC, BHPS, HILDA, SHP and SOEP (see Section 3.1 for more detailed information).

Source: Authors' calculations using the EU Survey of Income and Living Conditions (http://bit.ly/2flqXWd), the British Household Panel Survey (https://www.iser.essex.ac.uk/bhps), the Survey of Household, Income and Labour Dynamics in Australia (https://www.melbourneinstitute.com/hilda/), the Swiss Household Panel and the German Socio-Economic Panel (https://www.diw.de/en/soep).

\subsection{Policy indicators}

21. In a first step, the investigation focuses on reforms that make product markets or employment protection more flexible. For this purpose, it uses OECD indicators of regulation ranging from 0 (most flexible) to 6 (tightest):

- Job protection: The OECD indices of employment protection legislation for regular and temporary contracts (EPL-R and EPL-T) are available annually since 1985.

- Product market regulation

- the economy-wide OECD product market regulation (PMR) index, which summarises the economy-wide regulatory environment for product market competition: The OECD PMR indicator is only available every five years from 1998, implying that it cannot be used to analyse the dynamics of adjustment over the long term.

- the OECD indicator of regulation in energy, transport and communications (ETCR): The ETCR indicator is available annually from 1975.

22. In a second step, the analysis looks at how the effects of flexibility-enhancing reforms on transition probabilities depend on framework conditions created by other policies and institutions. The following indicators are used to measure framework conditions:

- $\quad$ Spending on active labour market policies (ALMP): The indicator is calculated as spending per unemployed as a percentage of GDP per capita, similarly to de Serres and Murtin (2013), to take out cyclical and automatic changes due to changes in unemployment. Sub-indicators measure ALMP expenditure on public employment services and training. Overall ALMP comprises 
employment services, training, employment incentives, integration of the disabled, direct job creation and start-up incentives (Adema et al., 2011).

- Coordination in wage setting: As OECD (2011), the analysis uses the ICTWSS index of the degree of coordination in wage setting. The index measures the level at which wages are predominantly coordinated, from 1 (fragmented wage bargaining) to 5 (strong degree of coordination). It gauges the expected effective degree, rather than the legal type, of coordination (Visser, 2015).

23. The investigation uses the variation of EPL and PMR indicators within countries over time to identify long-term effects of flexibility-enhancing reforms and adjustment paths towards the long-term effects. A decline in any of these indicators signals flexibility-enhancing reforms. ${ }^{4}$

24. Figure 2 shows the number of flexibility-enhancing reforms by country during 1994-2011. Liberalisation episodes in network industries were the most frequent category of structural reforms that OECD countries undertook, as highlighted by Høj et al. (2006), Duval (2008) and Bouis et al. (2012). Several reforms of job protection reduced the protection of regular contracts and facilitated the use of temporary contracts.

Figure 2. Number of reforms by country in the sample

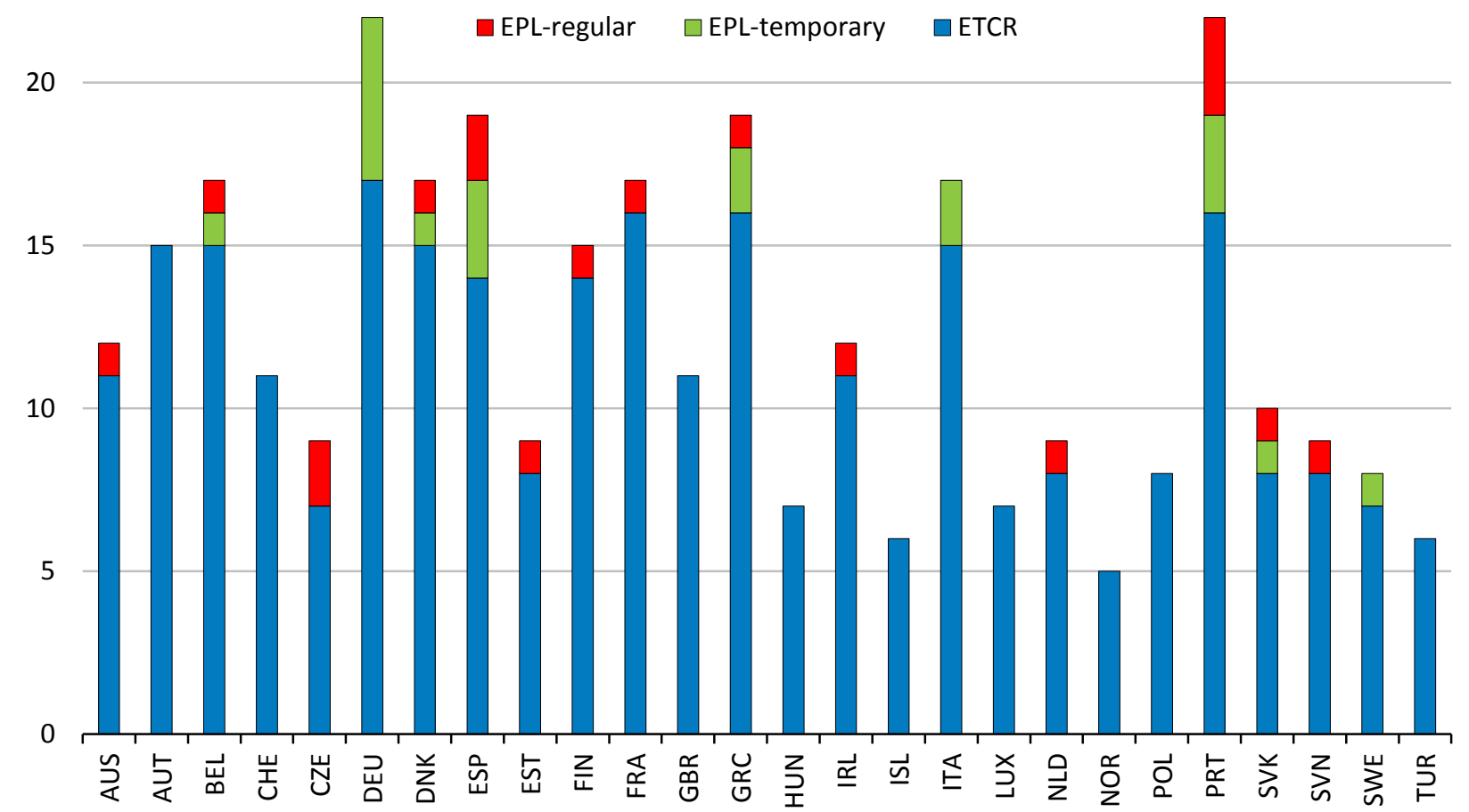

Note: A flexibility-enhancing reform occurs when the ETCR, EPL-regular or EPL-temporary index falls. The sample covers 19942011, although with differences across countries depending on the availability of data (see Table 1). ETCR is the Energy, Transport and Communication Regulation index and EPL is the Employment Protection Legislation index for regular or temporary contracts. The indices range from 0 (very flexible policy) to 6 (very restrictive policy).

Source: Authors' calculations using the OECD Employment Database (http://oe.cd/1Dp) and OECD Product Market Regulation database (http://oe.cd/1Dq).

4. These indicators are measured as of 1 January of the corresponding year of release. A change in year $t$ therefore means that $t$ is the first full year when the reform was in force. 
25. Table 3 shows the size of a typical reform. This size is measured as the mean rolling-window five-year change in the indicator across countries where this indicator declined. ${ }^{5}$

- A typical flexibility-enhancing reform of temporary contracts reduces EPL-T by 0.8 points, while a typical reform of regular contracts reduces EPL-R by 0.3 points.

- Product market regulation (PMR) indices, which measure regulations affecting competition across the economy, are only available for 1998, 2003 and 2008 in the sample period. ${ }^{6}$ A typical reform that increases product market competition lowers the PMR indicator by 0.34 points over five years. By comparison, a typical regulatory reform in network industries lowers the ETCR indicator by 0.92 points over five years.

Table 3. Typical labour and product market reforms in OECD countries

Average five-year changes in the policy indicator over reform episodes

\begin{tabular}{lcccc}
\hline & Mean & $\begin{array}{c}\text { Standard } \\
\text { deviation }\end{array}$ & Largest & Smallest \\
\hline EPL-regular & -0.30 & 0.28 & -1.19 & -0.05 \\
EPL-temporary & -0.81 & 0.65 & -2.38 & -0.13 \\
PMR & -0.34 & 0.17 & -0.66 & -0.01 \\
ETCR & -0.92 & 0.42 & -2.12 & -0.04 \\
\hline
\end{tabular}

Note: Mean refers to the mean of the five-year rolling-window change of the 26 OECD countries in the sample taking into account only negative changes (see Table 1 for more details on the years and countries included in the sample). ETCR is the Energy, Transport and Communication Regulation index and EPL is the Employment Protection Legislation index for regular and temporary contracts. PMR is the Product Market Regulation index and measures the economy-wide regulatory environment in 1998, 2003 and 2008. The indices range from 0 (very flexible policy) to 6 (very restrictive policy).

Source: Authors' calculations using the OECD Employment Database (http://oe.cd/1Dp) and OECD Product Market Regulation database (http://oe.cd/1Dq).

\subsection{Econometric framework}

26. The estimation strategy first analyses long-term effects of policies. It investigates adjustment paths following reforms in a second step.

27. The baseline specification uses Bassanini and Duval's $(2006,2009)$ empirical strategy to estimate long-term policy effects on transitions out of employment:

$$
f_{i c t}^{E L}=\alpha_{c}+\tau_{t}+\beta X_{i c t}+\gamma Z_{c t}+\rho P_{c t}+\varepsilon_{i c t} .
$$

28. Here, $f_{i c t}^{E L}$ counts transitions out of employment for individual $i$, who lives in country $c$, in year $t$. After substituting $f_{i c t}^{L E}$ for $f_{i c t}^{E L}$ on the left-hand side, the same equation evaluates policy effects on transitions into employment. The regressions estimate a linear generalised probability model using ordinary least squares (OLS). ${ }^{7}$ The idiosyncratic disturbances are denoted by $\varepsilon_{i c t}$.

5. A very few temporary upticks occurred during trend falls in regulation indicators. Where the indicator fell, these upticks are excluded when calculating the mean change across countries.

6. The micro-level databases underpinning the current study end in 2012 and so do not cover the most recent available year for the economy-wide PMR indicator (2013).

7. The model is called generalised because micro-level outcome variables take integer values between 0 and 6. 
29. Assuming the control variables and fixed effects capture all confounding variation, the parameter of interest $\rho$ indicates the average long-term impact of policy $P_{t}$ across the population. $P_{t}$, as described in the previous subsection, is the level of the policy indicator. A negative coefficient $\rho$ means that deregulation is linked with an increase in the outcome variable. The vector of individual control variables, $X_{i c t}$, covers: age and its squared value, being head of household, being in a couple, education level and lagged income quartile. The vector of country-level control variables, $Z_{c t}$, comprises government employment, population growth and the output gap. The regression includes country fixed effects, $\alpha_{c}$, and time fixed effects, $\tau_{t}$. It does not have individual fixed effects, in contrast with frequent practice for microlevel income regressions, because labour market transitions are relatively rare events and sample rotation is very high (with the dataset following most individuals for less than four years).

30. A second step extends the empirical framework to study the adjustment path over the short and medium term by adding $\sum_{j=0}^{T} \rho_{j} \Delta P_{c t-j}$ to Equation 8 . The resulting dynamic specification is highly flexible, imposing no particular constraint on the adjustment path, which contrasts with the rigidity of an error correction framework:

$$
f_{i c t}^{E L}=\alpha_{c}+\tau_{t}+\beta X_{i c t}+\gamma Z_{c t}+\rho P_{c t}+\sum_{j=0}^{T} \rho_{j} \Delta P_{c t-j}+\varepsilon_{i c t} .
$$

31. The time horizon $T$ in Equation 9 is set at 5. Adding lags does not reduce the number of observations much, because regulation indicators cover a longer period than the micro-level data.

32. The framework is further augmented to analyse how reform effects vary across population groups, with the following modified version of Equation 8:

$$
f_{i c t}^{E L}=\alpha_{c}+\tau_{t}+\beta X_{i c t}+\gamma Z_{c t}+\rho P_{c t}+\rho_{d} G_{d}\left(X_{i c t}\right) P_{c t}+\varepsilon_{i c t} .
$$

33. The model interacts the policy indicator $P_{c t}$ with a vector of dummy variables $G_{d}\left(X_{i c t}\right)$ indicating the group to which the individual belongs along the dimension of interest $d$. For instance, estimating whether effects vary depending on education uses a vector $G_{\text {education }}\left(X_{i c t}\right)$ of two dummy variables: less than high school and more than high school. Individuals who finished high school and took no higher education serve as the reference group. The parameter of interest, $\rho_{d}$, indicates the additional long-term impact of the reform for each population group in $G_{d}\left(X_{i c t}\right)$ with respect to the omitted group. In an illustrative example where deregulation increases the outcome variable for the omitted group, a positive coefficient in the vector $\rho_{d}$ indicates that deregulation has a smaller or even negative impact for the population group under consideration.

34. The analysis did not detect robust non-linear effects, whereby the effects of flexibility-enhancing policies would depend on their level. Different non-linear specifications, including adding squared terms or allowing for threshold effects, were implemented but did not yield stable, significant results.

35. The analysis investigates heterogeneity in reform effects by defining population groups along four dimensions: gender, age, education and income. These variables, which enter (8) as individual control variables, are also interacted with policies in (10). Income is defined as the average monthly labour earnings in the months of the previous year when the individual worked. Defining income quartiles based on the previous instead of current year avoids that high-earnings people among the non-employed at the end of the previous year would mechanically have a higher chance of having moved into employment by the end of this year.

36. In the baseline specification, a separate regression is run for the interaction of the policy variables with each of the four group definitions. In addition, alternative regressions have been run that interact the policy variables with all four group definitions simultaneously. This has the advantage that the reform 
effect identified for a particular population group, for example education group, controls for the composition of this group along the other dimensions, for example the age composition.

37. In another robustness check, the analysis of heterogeneous effects controls for country-specific, economy-wide shocks (Equation 11). It does so by including country-specific year fixed effects $\alpha_{c t}$, which have the advantage to control for any other factors of interest varying at the country level. This approach cannot be implemented to check robustness of (8), because country-specific year fixed effects would entirely absorb the average impact of the policy indicator.

$$
f_{i c t}^{E L}=\alpha_{c t}+\beta X_{i c t}+\rho P_{c t}+\rho_{d} G_{d}\left(X_{i c t}\right) P_{c t}+\varepsilon_{i c t} .
$$

38. All individual-level regressions in this paper cluster standard errors at the country-year level to match the level of variation of the policy indicator. This choice ensures that the very high number of observations does not artificially narrow standard errors, which instead reflect the variation of indicators over countries and years. Furthermore, since the panel is unbalanced and the number of observations varies from country to country, each observation receives a weight equal to the inverse of the total sample in a given country. This weighting avoids giving more importance to one country in one year because it would have more people in its sample than other ones. Each country and year is therefore considered as providing one observation from a policy perspective.

\section{Economy-wide results and their dynamics}

\subsection{Long-term relationships between more flexible policies and transitions in and out of employment}

39. Flexibility-enhancing reforms appear to hardly influence employment stability. They show few statistically significant effects on the risk of becoming jobless and chances of finding a job (Table 4). The estimates that stand out are that reforms making product markets more flexible increase the chance of becoming employed. For a typical regulatory reform of network industries (equal to a 0.92 fall in the ETCR indicator over five years), the coefficient indicates that job-finding chances increase by 3 percentage points across the economy. ${ }^{8}$ For a typical economy-wide product market reform (equal to a 0.34 fall in the PMR indicator over five years), the coefficient suggests that the chances of finding a job increase by 2 percentage points. The ETCR indicator is available annually since 1975 and hence offers greater variation than the PMR indicator, which is five-yearly and starts in 1998. Consequently, the estimation better identifies the effect of ETCR changes than PMR, as apparent in the standard errors and statistical confidence levels in Table 4. The regressions reveal no systematic link between EPL reforms and labour market transitions, which may be related to the small number of such reforms but also reflects that the average estimate masks differential impacts that depend on framework conditions (see Section 5).

8. The percentage point increase is obtained by multiplying the coefficient $(-0.03)$ with the typical five-year change of the indicator (-0.92), multiplied by 100 . 
ECO/WKP(2016)72

Table 4. Estimated effects of employment protection and product market regulation on worker transitions

\begin{tabular}{|c|c|c|c|c|c|c|}
\hline & $(1)$ & $(2)$ & (3) & $(4)$ & (5) & (6) \\
\hline \multicolumn{7}{|c|}{ A. Transition employment-joblessness } \\
\hline EPL-R & $\begin{array}{l}-0.013 \\
(0.012)\end{array}$ & & & & $\begin{array}{l}-0.008 \\
(0.013)\end{array}$ & $\begin{array}{l}-0.013 \\
(0.012)\end{array}$ \\
\hline EPL-T & & $\begin{array}{l}-0.001 \\
(0.003)\end{array}$ & & & $\begin{array}{c}-0.002 \\
(0.004)\end{array}$ & $\begin{array}{l}-0.001 \\
(0.003)\end{array}$ \\
\hline PMR & & & $\begin{array}{l}-0.021 \\
(0.013)\end{array}$ & & $\begin{array}{l}-0.019 \\
(0.013)\end{array}$ & \\
\hline ETCR & & & & $\begin{array}{l}-0.005 \\
(0.004) \\
\end{array}$ & & $\begin{array}{c}-0.002 \\
(0.005) \\
\end{array}$ \\
\hline $\begin{array}{l}\mathrm{N} \text { of obs } \\
\mathrm{N} \text { of clusters } \\
\mathrm{R}^{2}\end{array}$ & $\begin{array}{c}1088520 \\
263 \\
0.038\end{array}$ & $\begin{array}{c}1088520 \\
263 \\
0.038\end{array}$ & $\begin{array}{c}934062 \\
224 \\
0.039\end{array}$ & $\begin{array}{c}1125561 \\
271 \\
0.037\end{array}$ & $\begin{array}{c}932202 \\
224 \\
0.039\end{array}$ & $\begin{array}{c}1088520 \\
263 \\
0.038\end{array}$ \\
\hline & \multicolumn{6}{|c|}{ B. Transition joblessness-employment } \\
\hline EPL-R & $\begin{array}{c}-0.004 \\
(0.018)\end{array}$ & & & & $\begin{array}{c}0.027 \\
(0.026)\end{array}$ & $\begin{array}{c}0.009 \\
(0.019)\end{array}$ \\
\hline EPL-T & & $\begin{array}{l}-0.005 \\
(0.005)\end{array}$ & & & $\begin{array}{l}-0.011 \\
(0.009)\end{array}$ & $\begin{array}{c}0.003 \\
(0.006)\end{array}$ \\
\hline PMR & & & $\begin{array}{l}-0.061^{*} \\
(0.036)\end{array}$ & & $\begin{array}{l}-0.064^{\star} \\
(0.035)\end{array}$ & \\
\hline ETCR & & & & $\begin{array}{c}-0.030^{* * *} \\
(0.009)\end{array}$ & & $\begin{array}{c}-0.034^{* * *} \\
(0.010)\end{array}$ \\
\hline N obs & 398997 & 398997 & 336651 & 409395 & 336457 & 398997 \\
\hline $\mathrm{N}$ of clusters & 263 & 263 & 224 & 271 & 224 & 263 \\
\hline $\mathrm{R}^{2}$ & 0.196 & 0.196 & 0.197 & 0.196 & 0.196 & 0.196 \\
\hline
\end{tabular}

Note: Joblessness refers to unemployment or being out of the labour force. All regressions are estimated by OLS, assuming a linear generalised probability model. They include age, age squared, education level, average monthly labour income quartile, gender, output gap, government employment, population growth, country and year fixed effects. EPL is the OECD index of the strictness of Employment Protection Legislation. R stands for regular contracts, T for temporary ones. ETCR is the OECD index of Energy, Transport and Communication Regulation. PMR is the OECD Product Market Regulation index. ${ }^{* *}$ indicates significance at the $1 \%$ level, ${ }^{* *}$ at the $5 \%$ level and ${ }^{*}$ at the $10 \%$ level. The regressions are run on micro-level data covering 26 OECD countries over 1994 2012 (see Table 1 for details on the sample coverage). Standard errors are clustered at the country-year level.

Source: Authors' calculations using the European Community Household Panel (http://bit.ly/2gjPZ10), the EU Survey of Income and Living Conditions (http://bit.ly/2flqXWd), the British Household Panel Survey (https://www.iser.essex.ac.uk/bhps), the Survey of Household, Income and Labour Dynamics in Australia (https://www.melbourneinstitute.com/hilda/), the Swiss Household Panel and the German Socio-Economic Panel (https://www.diw.de/en/soep), the OECD Employment database (http://oe.cd/1Dp), the OECD Product Market Regulation database (http://oe.cd/1Dq) and the OECD Economic Outlook database (http://oe.cd/1Dr).

40. Robustness checks have been conducted in two ways. First, employment protection and product market regulation policy variables have been included simultaneously (Columns 5 and 6) to examine whether systematic links between policy settings in the two areas could influence the results obtained when introducing indicators one by one. The significant effects of more flexible product market regulation (measured by ETCR or PMR) remain virtually unchanged in both size and significance. These are the core results shown in Figure 3. Second, the regressions have been re-run at the country level after aggregating individual variables (transition dummies and controls) into national average transition probabilities. The results, which are not reported, are very similar to the ones obtained at the individual level. The individuallevel regressions serve as the baseline because they control for the effect of individual characteristics on outcomes. Finally, other policy variables have been included in the baseline specification of Table 4 . The sample size is reduced significantly by $30 \%$. Results are robust to adding other policy variables (see Appendix A1), and indeed the changes in the size and significance of some coefficients are more related to the sample reduction than to the inclusion of other policy variables.

41. Most of the coefficients would suggest that reforms making employment protection or product market regulation more flexible, which reduce the values of the indicators, increase transition probabilities from and to employment and joblessness. However, these effects are not statistically significant, apart from 
the above-discussed effects of product market deregulation on job finding chances. Analysis in Sections 5 and 6 indicates that these overall coefficients average out effects that vary depending on framework conditions and people's characteristics. These differences across framework conditions and groups may explain why average effects turn out to lack statistical significance in overall regressions.

\section{Figure 3. The impact of typical flexibility-enhancing reforms on transition probabilities}

\section{A. Transition probability employment-joblessness}

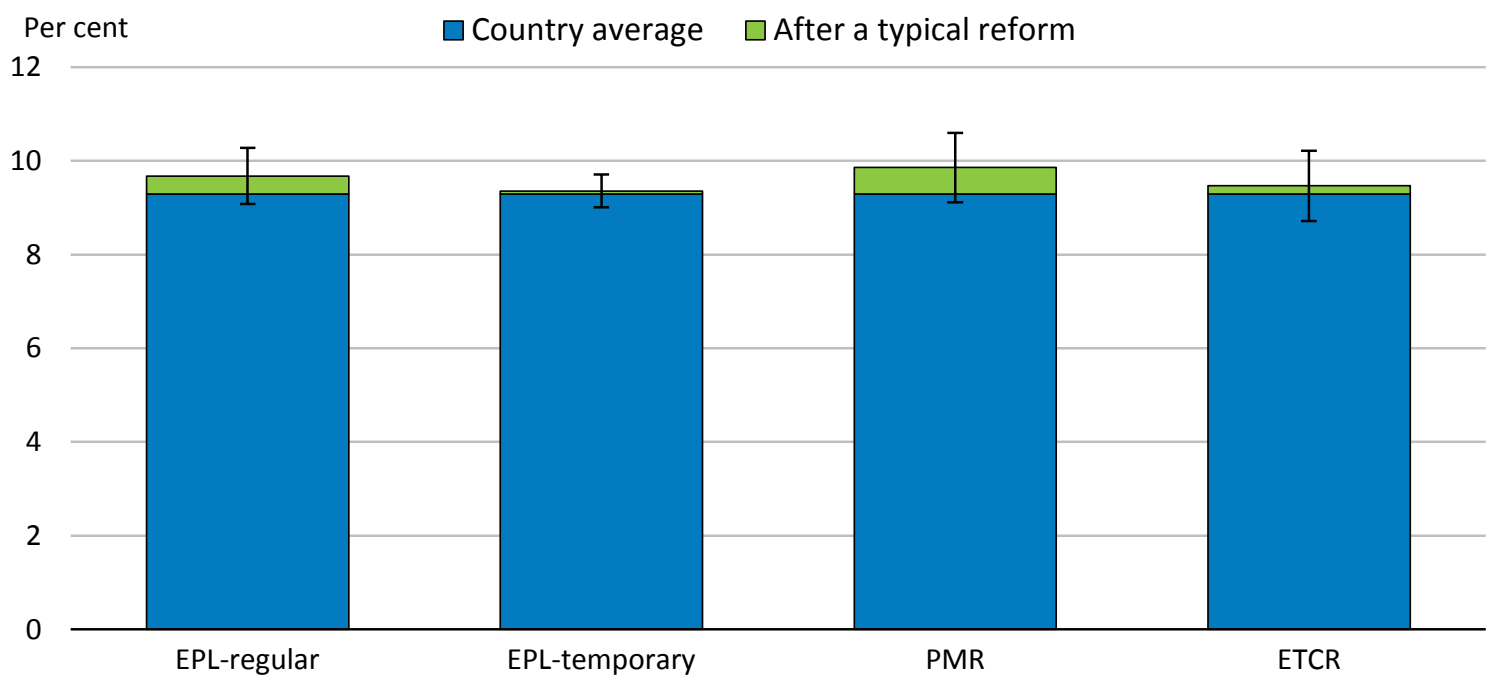

B. Transition probability joblessness-employment

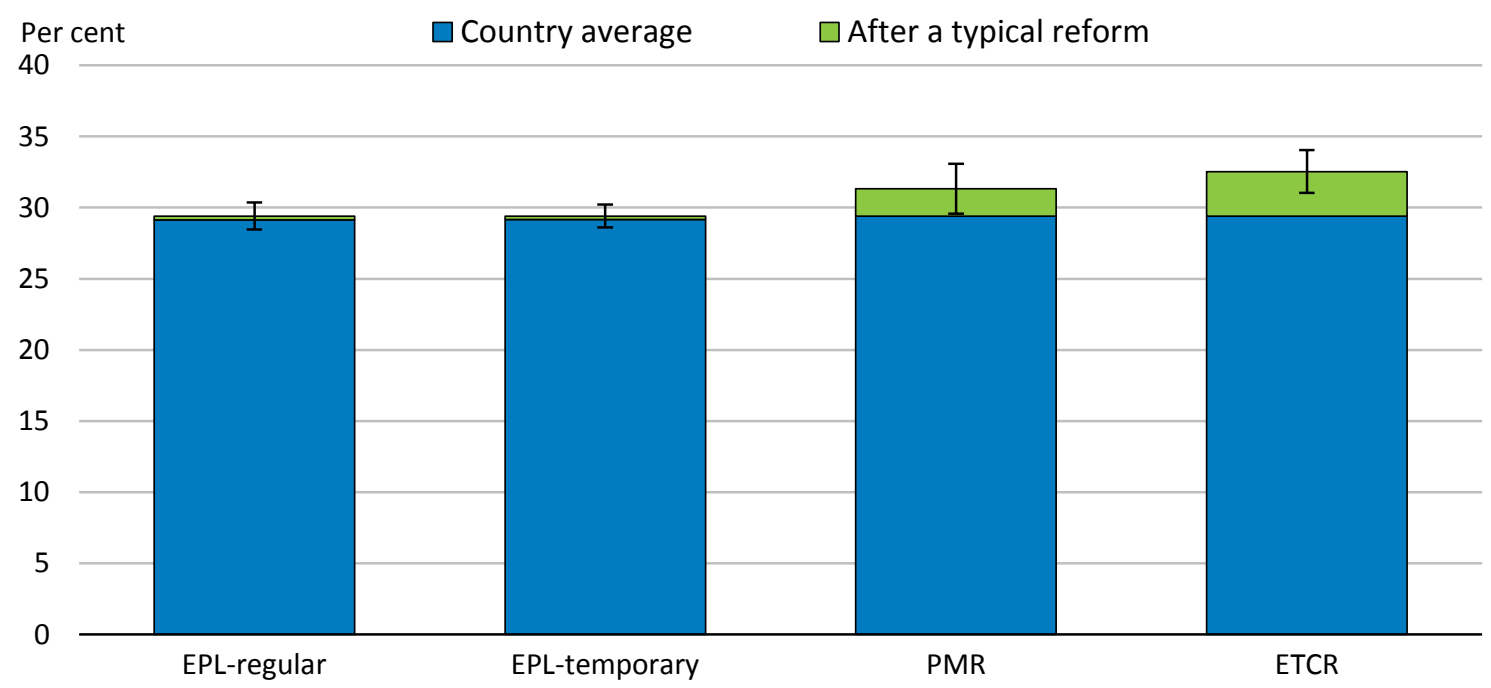

Note: The blue bars indicate the average rate across 26 OECD countries in the sample. The green bars indicate the impact of a typical flexibility-enhancing reform, obtained by multiplying the coefficients in Table 4 (using Column 6 for EPL and ETCR and Column 5 for PMR) by the five-year change of the respective policy indicator (see Table 3). The thin lines represent the $90 \%$ confidence bands. The estimations are carried out on micro-level data covering 26 OECD countries over 1994-2012 (see Table 1 for details on the sample coverage).

Source: Authors' calculations using the European Community Household Panel (http://bit.ly/2gjPZ10), the EU Survey of Income and Living Conditions (http://bit.ly/2flqXWd), the British Household Panel Survey (https://www.iser.essex.ac.uk/bhps), the Survey of Household, Income and Labour Dynamics in Australia (https://www.melbourneinstitute.com/hilda/), the Swiss Household Panel and the German Socio-Economic Panel (https://www.diw.de/en/soep), the OECD Employment database (http://oe.cd/1Dp), the OECD Product Market Regulation database (http://oe.cd/1Dq) and the OECD Economic Outlook database (http://oe.cd/1Dr). 
42. These results are consistent with existing aggregate evidence on the employment effects of labour and product market reforms. Changes in EPL have no statistically significant economy-wide permanent effects on transitions, implying no permanent changes in employment rates. This finding is consistent with evidence that the tightness of job protection does not significantly influence employment rates (OECD, 2007; Gal and Theising, 2015). Conversely, relaxing product market regulation has no permanent significant effect on transitions out of employment and a positive effect on transitions into employment, suggesting a rise in employment, also consistent with aggregate evidence (OECD, 2007; Gal and Theising, 2015). The present results are meant to provide a better understanding of employment stability, which has very important consequences for well-being, over and above its implications for aggregate employment. Aggregate data are better suited to analyse aggregate effects, because working at the country rather than individual level allows covering more countries over longer periods.

\subsection{Decomposing joblessness into unemployment and economic inactivity}

43. The transitions were defined until now as transitions out of and into employment, while making no distinction between unemployment and economic inactivity. Table 5 shows the impact of policies on transitions when decomposing joblessness into these two components. ${ }^{9}$ Reforms making product market regulation more flexible increase the transition probability from employment to unemployment (Table 5, Panel A1), while results on the probability of becoming jobless were insignificant. The impact of policies on the transition from employment to economic inactivity is insignificant (Table 5, Panel A2).

9. The labour market status is self-declared in all the household surveys this paper uses. 
Table 5. Estimated effects of flexibility-enhancing reforms on transition rates into and out of unemployment and economic inactivity

\begin{tabular}{|c|c|c|c|c|}
\hline \multirow[b]{2}{*}{ EPL-R } & \multicolumn{2}{|c|}{$\begin{array}{c}\text { A1. Transition } \\
\text { employment-unemployment }\end{array}$} & \multicolumn{2}{|c|}{$\begin{array}{c}\text { A2. Transition } \\
\text { employment-inactivity }\end{array}$} \\
\hline & $\begin{array}{l}-0.007 \\
(0.009)\end{array}$ & $\begin{array}{l}-0.008 \\
(0.007)\end{array}$ & $\begin{array}{l}-0.001 \\
(0.006)\end{array}$ & $\begin{array}{l}-0.004 \\
(0.006)\end{array}$ \\
\hline EPL-T & $\begin{array}{l}-0.005^{* *} \\
(0.002)\end{array}$ & $\begin{array}{l}-0.002 \\
(0.002)\end{array}$ & $\begin{array}{c}0.003 \\
(0.003)\end{array}$ & $\begin{array}{c}0.001 \\
(0.002)\end{array}$ \\
\hline PMR & $\begin{array}{c}-0.022^{\star \star \star *} \\
(0.007)\end{array}$ & & $\begin{array}{c}0.003 \\
(0.009)\end{array}$ & \\
\hline ETCR & & $\begin{array}{l}-0.008^{* *} \\
(0.003)\end{array}$ & & $\begin{array}{c}0.005 \\
(0.003) \\
\end{array}$ \\
\hline $\begin{array}{l}\mathrm{N} \text { obs } \\
\mathrm{N} \text { of clusters } \\
\mathrm{R}^{2}\end{array}$ & $\begin{array}{c}932202 \\
224 \\
0.025\end{array}$ & $\begin{array}{c}1088520 \\
263 \\
0.024\end{array}$ & $\begin{array}{c}932202 \\
224 \\
0.029\end{array}$ & $\begin{array}{c}1088520 \\
263 \\
0.030\end{array}$ \\
\hline & $\begin{array}{r}\text { B1. } \\
\text { unemployr }\end{array}$ & $\begin{array}{l}\text { ition } \\
\text { mployment }\end{array}$ & $\begin{array}{r}\mathrm{B} 2 \\
\text { inactivi }\end{array}$ & $\begin{array}{l}\text { ition } \\
\text { loyment }\end{array}$ \\
\hline EPL-R & $\begin{array}{c}0.033 \\
(0.039)\end{array}$ & $\begin{array}{c}0.011 \\
(0.029)\end{array}$ & $\begin{array}{c}0.028 \\
(0.038)\end{array}$ & $\begin{array}{c}0.018 \\
(0.024)\end{array}$ \\
\hline EPL-T & $\begin{array}{l}-0.000 \\
(0.014)\end{array}$ & $\begin{array}{l}0.003 \\
(0.009)\end{array}$ & $\begin{array}{l}-0.004 \\
(0.008)\end{array}$ & $\begin{array}{l}0.012^{\star *} \\
(0.005)\end{array}$ \\
\hline PMR & $\begin{array}{l}-0.024 \\
(0.049)\end{array}$ & & $\begin{array}{l}-0.047^{*} \\
(0.027)\end{array}$ & \\
\hline ETCR & & $\begin{array}{c}0.002 \\
(0.012)\end{array}$ & & $\begin{array}{c}-0.034^{* * *} \\
(0.010)\end{array}$ \\
\hline N obs & 92317 & 109783 & 244140 & 289214 \\
\hline $\begin{array}{l}\mathrm{N} \text { of clusters } \\
\mathrm{R}^{2}\end{array}$ & $\begin{array}{c}224 \\
0.155\end{array}$ & $\begin{array}{c}263 \\
0.153\end{array}$ & $\begin{array}{c}224 \\
0.185\end{array}$ & $\begin{array}{c}263 \\
0.181\end{array}$ \\
\hline
\end{tabular}

Note: All regressions are estimated by OLS, assuming a linear generalised probability model. They include age, age squared, education level, average monthly labour income quartile, gender, output gap, government employment, population growth, country and year fixed effects. EPL is the OECD index of the strictness of Employment Protection Legislation. R stands for regular contracts, T for temporary ones. ETCR is the OECD index of Energy, Transport and Communication Regulation. PMR is the OECD Product Market Regulation index. ${ }^{* * *}$ indicates significance at the $1 \%$ level, ${ }^{* *}$ at the $5 \%$ level and ${ }^{*}$ at the $10 \%$ level. The regressions are run on micro-level data covering 26 OECD countries over 1994-2012 (see Table 1 for details on the sample coverage). Standard errors are clustered at the country-year level.

Source: Authors' calculations using the European Community Household Panel (http://bit.ly/2gjPZ10), the EU Survey of Income and Living Conditions (http://bit.ly/2flgXWd), the British Household Panel Survey (https://www.iser.essex.ac.uk/bhps), the Survey of Household, Income and Labour Dynamics in Australia (https://www.melbourneinstitute.com/hilda/), the Swiss Household Panel and the German Socio-Economic Panel (https://www.diw.de/en/soep), the OECD Employment database (http://oe.cd/1Dp), the OECD Product Market Regulation database (http://oe.cd/1Dq) and the OECD Economic Outlook database (http://oe.cd/1Dr).

44. The results suggest that reforms making product markets more flexible increase the probability of finding a job mainly because they boost the probability of becoming employed among economically inactive people. Such reforms are found to increase transitions from inactivity to employment, while the estimated effect on transitions from unemployment to employment is statistically insignificant and in the case of network reforms even of the opposite sign (Table 5, Panels B1 and B2). ${ }^{10}$ A typical regulatory reform of network industries, as measured by the ETCR index, increases the probability of becoming employed from inactivity by 3 percentage points for workers across the economy, from a sample average of $20 \%$ (Figure 4).

10. The coefficient of PMR reforms on the unemployment-employment transition probability (0.024) is i) statistically insignificant, ii) smaller than that on the inactivity-employment transition probability (0.047), and iii) applies to a narrower section of the population (unemployed vs. economically inactive people). 
45. The strong role of inactivity-employment transitions in explaining the job finding benefit of product market reforms is consistent with the view that product market reforms boost real wages, drawing people who are marginally attached to the labour force into it. Past OECD work underscored that product market reforms boost employment by raising real wages and thus labour supply (Nicoletti and Scarpetta, 2005; Bassanini and Duval, 2009).

\section{Figure 4. Estimated effects of flexibility-enhancing reforms on transition probabilities into and out of unemployment and economic inactivity}

\section{A1. Transition rate employment-unemployment}

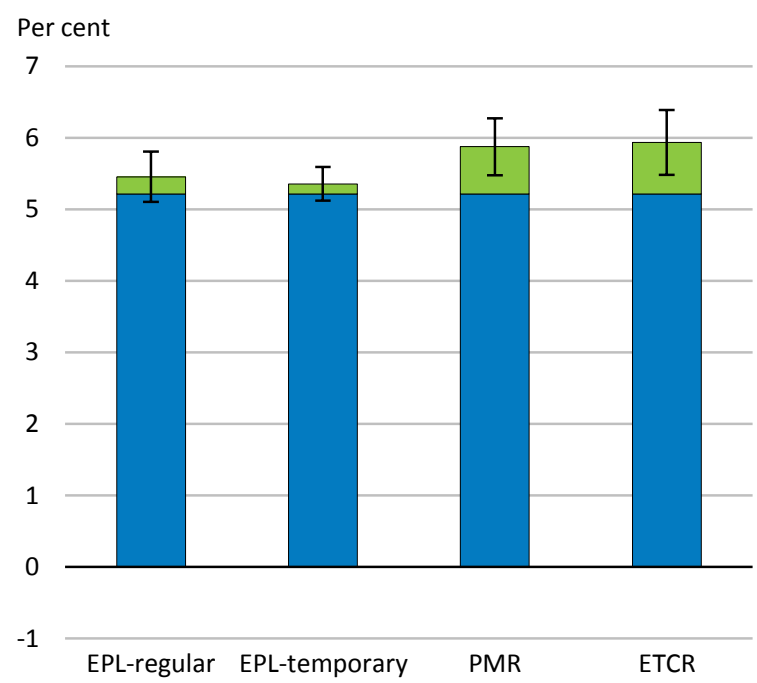

B1. Transition rate unemployment-employment

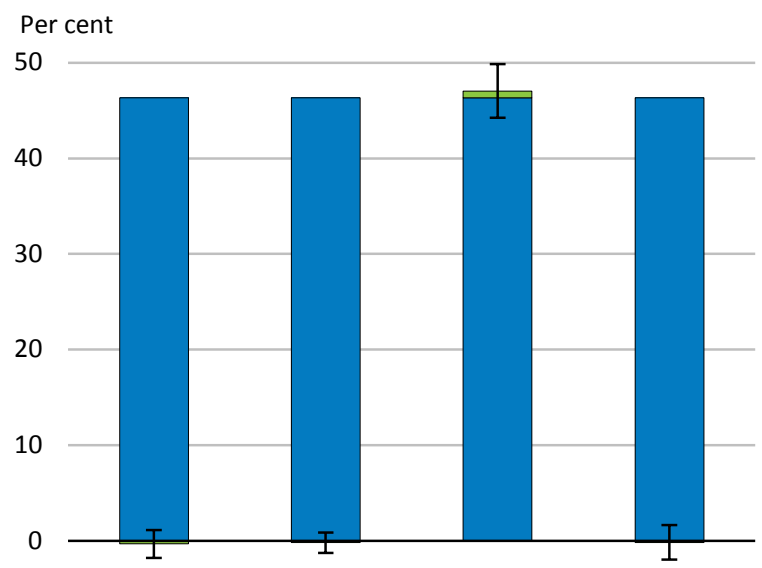

$-10$

$$
\text { EPL-regular EPL-temporary PMR ETCR }
$$

A2. Transition rate employment-inactivity

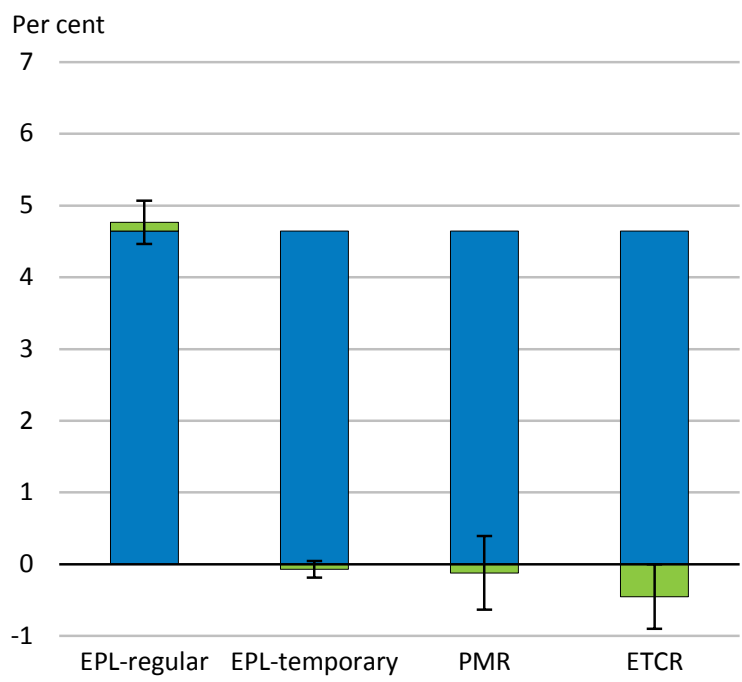

B2. Transition rate inactivity-employment Per cent 50

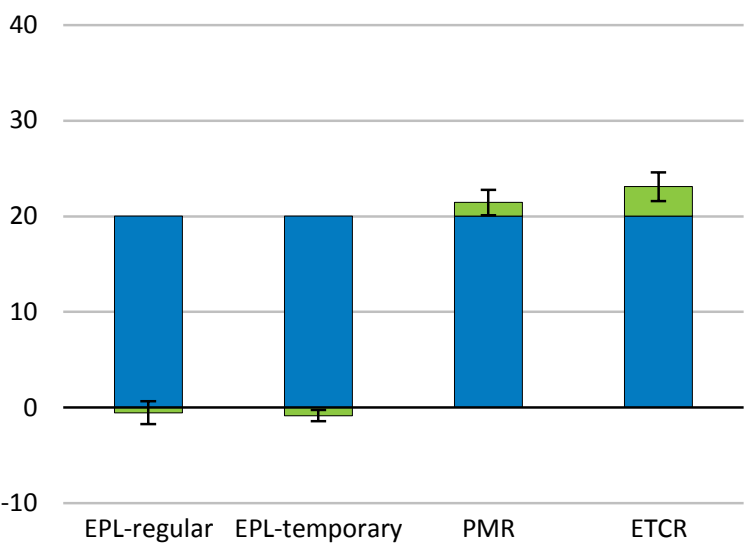

Note: The blue bars indicate the average rate across 26 OECD countries in the sample. The green bars indicate the impact of a typical flexibility-enhancing reform, obtained by multiplying the coefficients in Table 5 by the five-year change of the respective policy indicator (Table 3). The coefficients and significance levels reported are taken from the second column of each panel in Table 5 for the EPL and ETCR indices, and from the first column for the PMR index. The thin lines represent the $90 \%$ confidence bands. The estimations are carried out on micro-level data covering 26 OECD countries over 1994-2012 (see Table 1 for details on the sample coverage).

Source: Authors' calculations using the European Community Household Panel (http://bit.ly/2gjPZ10), the EU Survey of Income and Living Conditions (http://bit.ly/2flqXWd), the British Household Panel Survey (https://www.iser.essex.ac.uk/bhps), the Survey of Household, Income and Labour Dynamics in Australia (https://www.melbourneinstitute.com/hilda/), the Swiss Household Panel and the German Socio-Economic Panel (https://www.diw.de/en/soep), the OECD Employment database (http://oe.cd/1Dp), the OECD Product Market Regulation database (http://oe.cd/1Dq) and the OECD Economic Outlook database (http://oe.cd/1Dr). 


\subsection{Job-to-job flows}

46. The analysis could not uncover effects of reforms enhancing economic flexibility on job-to-job transitions that do not involve a period of non-employment (Table A2.1 in Appendix A2). The reason is not necessarily that flexibility reforms have no such effects but rather that the micro-level panel data used for this study do not track job-to-job changes as well as transitions in and out of employment. The datasets gathered and harmonised for this study measure job-to-job transitions at annual frequency and employment transitions at monthly frequency. Earlier OECD analysis documented that more stringent employment protection for regular contracts substantially reduces job-to-job flows (Bassanini and Garnero, 2013).

\subsection{Dynamic effects}

47. Dynamic estimations reveal different adjustment speeds, generally with weak statistical significance. As mentioned above, Equation 9 is used. Dynamic effects of reforms that make product market regulation more flexible can be investigated only through the ETCR lens, because the PMR indicator is only available every five years.

48. The clearest effects arise for reforms that make network industry regulation more flexible (Figure 5). Such reforms are followed by an immediate increase in the risk of becoming jobless, which is economically large (two percentage points for a unit fall in the ETCR index) and statistically significant at the 5\% level. This increase in the risk of becoming jobless quickly becomes statistically insignificant and economically indistinguishable from zero and then negative. ETCR reform is followed by a reduction in the risk of moving out of employment six years after its implementation. On the other hand, these reforms are associated with a gradual rise in the chances of finding a job, which becomes economically large and highly statistically significant after four years. This result is consistent with Gal and Theising's (2015) conclusion that regulatory reform of network industries boosts the aggregate employment rate. Denk (2016) finds that network industry reform increases entry and exit rates in the sector without persistently affecting employment in these industries. OECD (2016) identifies that reforming network industries reduces their employment level temporarily but not in the long term while boosting employment in other sectors. The results from Denk (2016), OECD (2016), Gal and Theising (2015) and the present paper indicate that employment in other sectors, that use network industry outputs, benefits from network industry deregulation. 
Figure 5. Estimated dynamic economy-wide effects of ETCR deregulation

A. Employment-joblessness

Percentage points

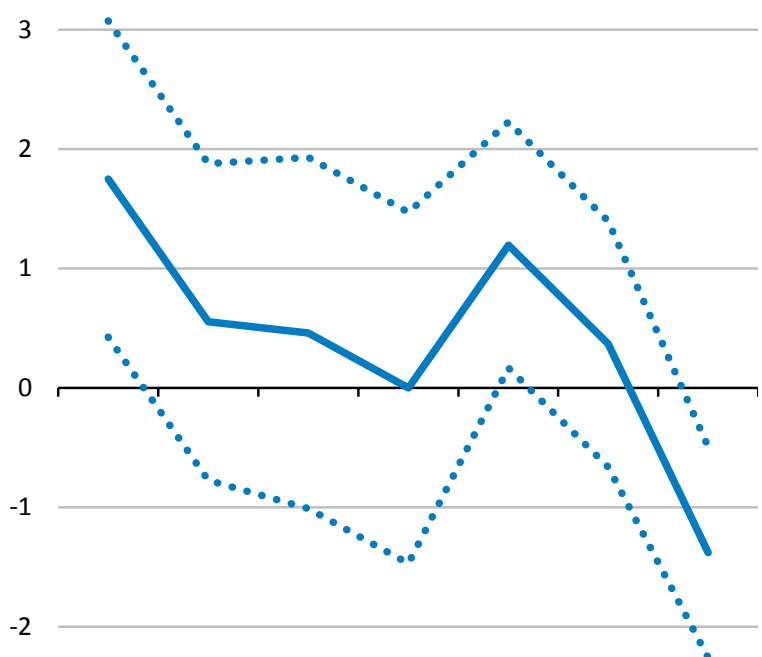

$-3$
Years after the reform

$\begin{array}{lllllll}0 & 1 & 2 & 3 & 4 & 5 & 6+\end{array}$

B. Joblessness-employment

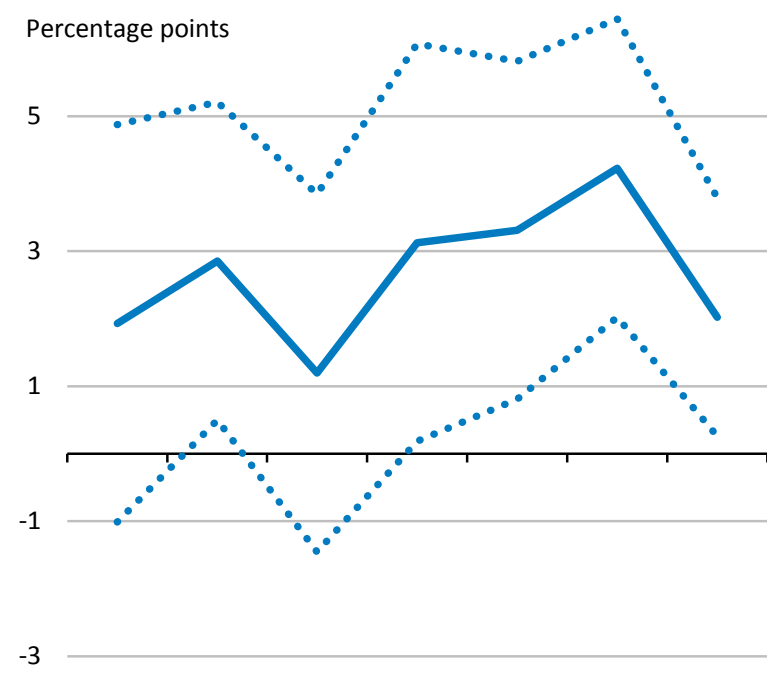

Years after the reform

Note: The estimates depict the reponse to a typical regulatory reform of network industries $(0.92$ reduction in the ETCR indicator, see Table 3). The dotted lines indicate the $90 \%$ confidence band. Estimates stem from OLS regressions using Equation 9. Standard errors are clustered at the country-year level. The estimations are carried out on micro-level data covering 26 OECD countries over 1994-2012 (see Table 1 for details on the sample coverage).

Source: Authors' calculations using the European Community Household Panel (http://bit.ly/2gjPZ10), the EU Survey of Income and Living Conditions (http://bit.ly/2flgXWd), the British Household Panel Survey (https://www.iser.essex.ac.uk/bhps), the Survey of Household, Income and Labour Dynamics in Australia (https://www.melbourneinstitute.com/hilda/), the Swiss Household Panel and the German Socio-Economic Panel (https://www.diw.de/en/soep), the OECD Employment database (http://oe.cd/1Dp), the OECD Product Market Regulation database (http://oe.cd/1Dq) and the OECD Economic Outlook database (http://oe.cd/1Dr).

49. The following results provide tentative evidence on the dynamic effects of easing employment protection (Figures 6 and 7). Most of the effects are statistically insignificant at standard confidence levels. After six years and more, a one-unit reduction in the EPL indicator for regular contracts is associated with an economically substantial and statistically marginally significant increase in jobless people's chances of finding a job. However, at the same horizon, this reform of employment protection is also associated with a noticeable increase in the risk of becoming jobless, although this change is not statistically significant at usual confidence levels. Similarly, making the use of temporary employment contracts more flexible produces effects that the dynamic estimation struggles to identify. 
ECO/WKP(2016)72

\section{Figure 6. Estimated dynamic effects of easing job protection for regular contracts}

A. Employment-joblessness

Percentage points

3

2

1

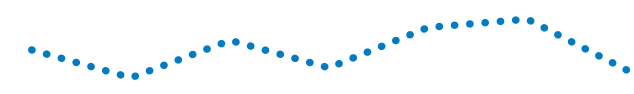

$-$

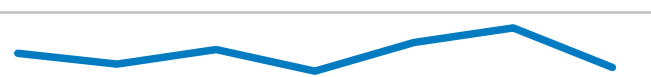

0

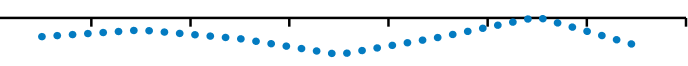

$-1$

$-2$

Years after the reform

$\begin{array}{lllllll}0 & 1 & 2 & 3 & 4 & 5 & 6+\end{array}$

B. Joblessness-employment

Percentage points

5

3

1

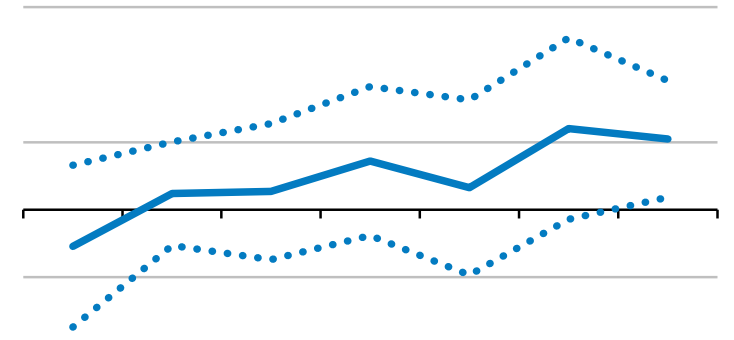

$-3$

Years after the reform

$\begin{array}{lllllll}0 & 1 & 2 & 3 & 4 & 5 & 6+\end{array}$

Note: The estimates depict the response to a typical reform of job protection for regular workers $(0.3$ decrease in the EPL-R indicator, see Table 3). The dotted lines indicate the $90 \%$ confidence band. Estimates stem from OLS regressions using Equation 9. Standard errors are clustered at the country-year level. The estimations are carried out on micro-level data covering 26 OECD countries over 1994-2012 (see Table 1 for details on the sample coverage).

Source: Authors' calculations using the European Community Household Panel (http://bit.ly/2gjPZ10), the EU Survey of Income and Living Conditions (http://bit.ly/2flqXWd), the British Household Panel Survey (https://www.iser.essex.ac.uk/bhps), the Survey of Household, Income and Labour Dynamics in Australia (https://www.melbourneinstitute.com/hilda/), the Swiss Household Panel and the German Socio-Economic Panel (https://www.diw.de/en/soep), the OECD Employment database (http://oe.cd/1Dp), the OECD Product Market Regulation database (http://oe.cd/1Dq) and the OECD Economic Outlook database (http://oe.cd/1Dr). 
Figure 7. Estimated dynamic effects of easing job protection for temporary contracts

\section{A. Employment-joblessness}

Percentage points

3

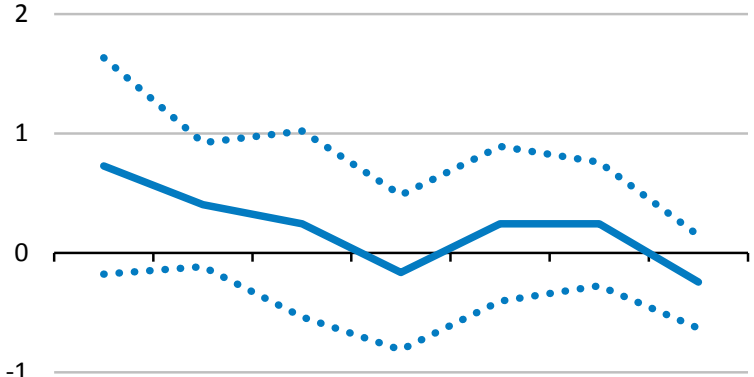

$-1$

$-2$

$-3$
B. Joblessness-employment
Percentage points

5

3

1

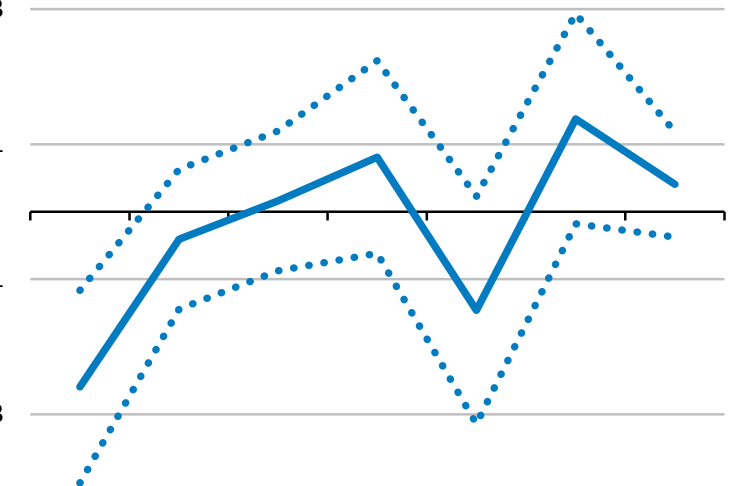

Years after the reform

Note: The estimates depict the response to a typical reform of job protection for temporary workers ( 0.81 decrease in the EPL-T indicator, see Table 3).. The dotted lines indicate the $90 \%$ confidence band. Estimates stem from OLS regressions using Equation 9. Standard errors are clustered at the country-year level. The estimations are carried out on micro-level data covering 26 OECD countries over 1994-2012 (see Table 1 for details on the sample coverage).

Source: Authors' calculations using the European Community Household Panel (http://bit.ly/2gjPZ10), the EU Survey of Income and Living Conditions (http://bit.ly/2flgXWd), the British Household Panel Survey (https://www.iser.essex.ac.uk/bhps), the Survey of Household, Income and Labour Dynamics in Australia (https://www.melbourneinstitute.com/hilda/), the Swiss Household Panel and the German Socio-Economic Panel (https://www.diw.de/en/soep), the OECD Employment database (http://oe.cd/1Dp), the OECD Product Market Regulation database (http://oe.cd/1Dq) and the OECD Economic Outlook database (http://oe.cd/1Dr).

\section{Influence of framework conditions on reform effects}

50. Framework conditions can influence the effect of labour and product market flexibility on employment stability. This section uses Bassanini and Duval's (2009) empirical framework to evaluate such influence, by adding interactions between framework conditions and flexibility-enhancing policies to Equation 8. It focuses on economically interpretable interactions among the very high number of potential combinations of policy variables and only discusses stable, statistically significant results.

\subsection{Active labour market policies and the chances of becoming employed}

51. Active labour market programmes are expected to make it easier for jobless people to become employed (de Serres and Murtin, 2014). More flexible hiring and firing rules could interact with active labour market programmes by simultaneously making workers better equipped for jobs and employers more willing to experiment with new hires. Results reported in Table 6 and Figure 8 are in line with this hypothesis. Restricting the sample to observations, for which data on ALMP spending are available, yields a negative and statistically significant coefficient on EPL-R, implying that a reduction in the employment protection of regular contracts is associated with increased hirings. This positive effect of EPL reform is stronger in countries that spend more on ALMP, as indicated by the negative and statistically significant coefficient on the interaction between EPL-R and ALMP. 
Table 6. Complementarity between employment protection reforms and ALMP spending for new hirings

\begin{tabular}{lccc}
\hline \multicolumn{3}{c}{ Transition joblessness-employment } \\
\hline Pol: & ALMP & Training & PES \\
\hline EPL-R & $-0.053^{* * *}$ & -0.023 & -0.024 \\
& $(0.017)$ & $(0.019)$ & $(0.019)$ \\
EPL-T & -0.011 & -0.006 & -0.009 \\
& $(0.008)$ & $(0.007)$ & $(0.007)$ \\
ETCR & $-0.043^{* * *}$ & $-0.035^{* * *}$ & $-0.062^{* * *}$ \\
& $(0.012)$ & $(0.012)$ & $(0.014)$ \\
Pol & $0.007^{* *}$ & $0.019^{*}$ & $0.024^{* *}$ \\
& $(0.003)$ & $(0.010)$ & $(0.010)$ \\
EPL-R*Pol & $-0.004^{* * *}$ & -0.007 & $-0.011^{* * *}$ \\
& $(0.001)$ & $(0.004)$ & $(0.004)$ \\
EPL-T*Pol & -0.001 & -0.000 & -0.009 \\
& $(0.001)$ & $(0.002)$ & $(0.006)$ \\
ETCR ${ }^{*}$ Pol & 0.002 & 0.001 & -0.000 \\
& $(0.001)$ & $(0.002)$ & $(0.006)$ \\
\hline N obs & 295058 & 311999 & 295940 \\
N of clusters & 235 & 235 & 235 \\
$R^{2}$ & 0.191 & 0.192 & 0.191 \\
\hline
\end{tabular}

Note: ALMP is spending on active labour market policies per unemployed as a percentage of GDP per capita; Training is an ALMP subcomponent, and PES is the subcomponent of ALMP related to public employment services and administration. The estimations are carried out on micro-level data covering 26 OECD countries over 1994-2012 (see Table 1 for details on the sample coverage).

Source: Authors' calculations using the European Community Household Panel (http://bit.ly/2gjPZ1o), the EU Survey of Income and Living Conditions (http://bit.ly/2flaXWd), the British Household Panel Survey (https://www.iser.essex.ac.uk/bhps), the Survey of Household, Income and Labour Dynamics in Australia (https://www.melbourneinstitute.com/hilda/), the Swiss Household Panel and the German Socio-Economic Panel (https://www.diw.de/en/soep), the OECD Employment database (http://oe.cd/1Dp), the OECD Product Market Regulation database (http://oe.cd/1Dq) and the OECD Economic Outlook database (http://oe.cd/1Dr).

52. Analysing different sources of this interaction suggests that it comes more from spending on public employment services than training programmes:

- The significant interaction with spending on public employment services may reflect that this spending category approximates the weight that labour market programmes put on job-search requirements. Strong job-search requirements have been identified as effective to shorten unemployment spells (Martin, 2014; Pareliussen, 2014).

- The observation that the interaction with spending on training for the unemployed is weaker and statistically insignificant is consistent with randomised experiments conducted in France (Crépon et al., 2015). In this study where training was randomly assigned among eligible unemployed workers, those who received training were subsequently more likely to find a job, but largely at the expense of those who did not receive training, so that the programme yielded little net benefit. 
Figure 8. The positive effect of activation programmes on the hiring benefits from employment protection reforms

Estimated percentage point changes in job-finding probabilities after a typical reform of job protection for regular contracts depending on ALMP spending relative to the average country

A. Active labour market policies

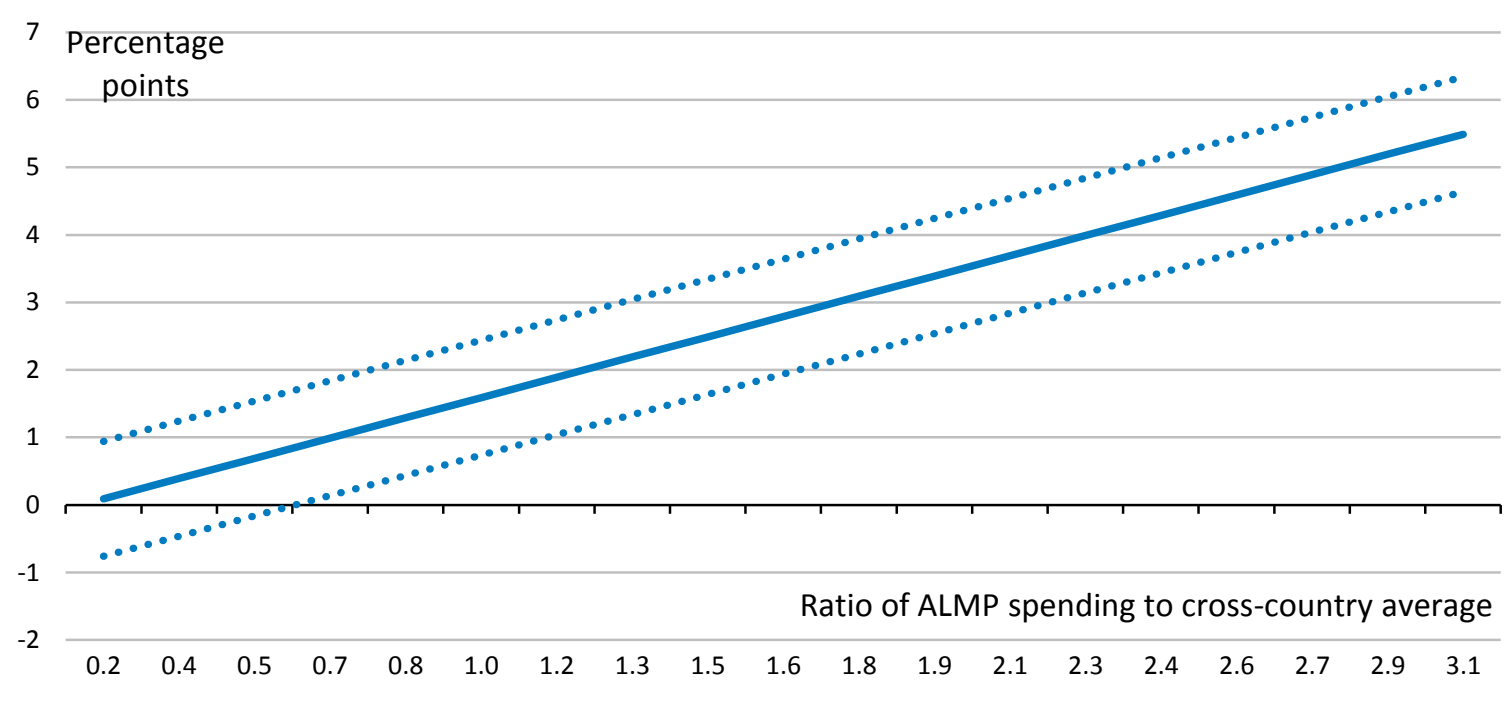

B. Public employment services

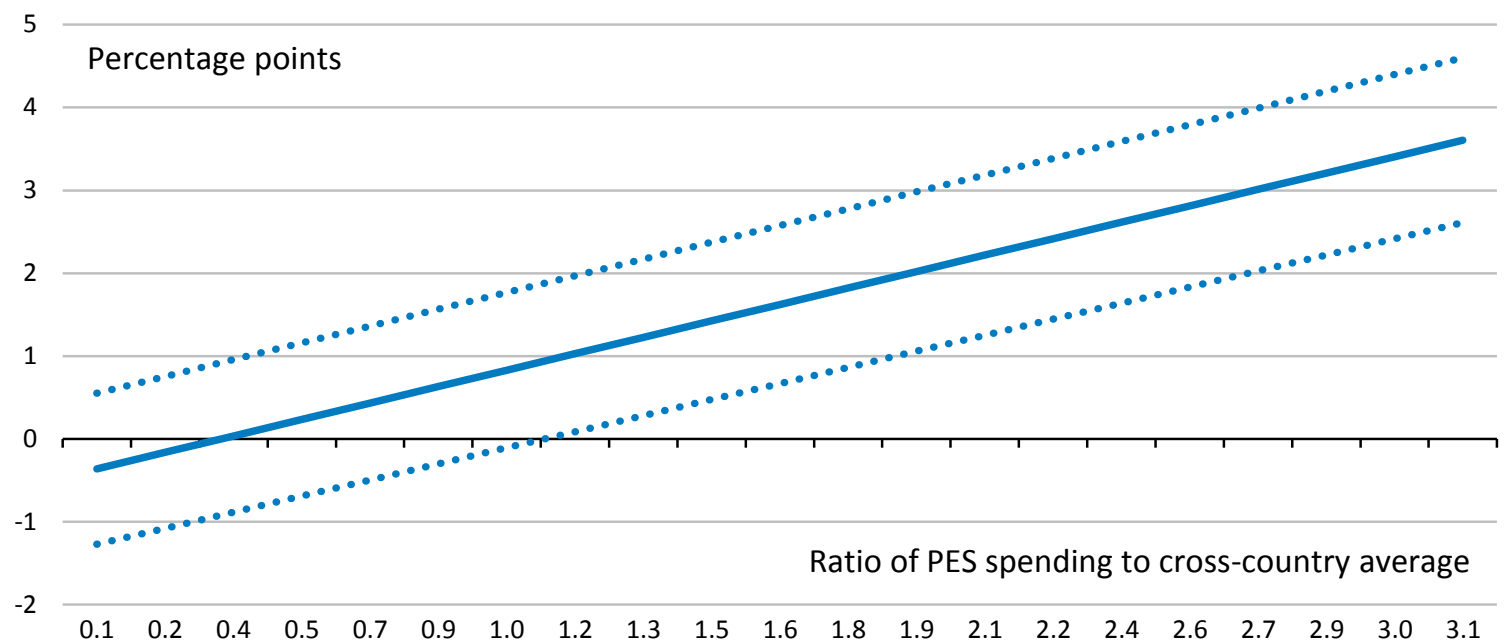

Note: Depending on how much a country spends on active labour market programmes (ALMP) for each person unemployed relative to the sample average, which determines its position on the horizontal axis, the solid line plots the impact of a typical reform of employment protection for regular contracts (EPL-R) on transition probabilities into employment from unemployment or economic inactivity. The impact of a typical EPL-R reform is obtained by multiplying the coefficient on EPL- $R^{\star} P$ ol in Table 6 with the size of a typical reform. For more information on reform measurement, see Section 3.3. The dotted lines show $90 \%$ confidence intervals. Public employment services are a subcomponent of overall spending on active labour market policies. The effects are estimated with micro-level data covering 26 OECD countries over 1994-2012 (see Table 1 for details on the sample coverage).

Source: Authors' calculations using the European Community Household Panel (http://bit.ly/2gjPZ10), the EU Survey of Income and Living Conditions (http://bit.ly/2flgXWd), the British Household Panel Survey (https://www.iser.essex.ac.uk/bhps), the Survey of Household, Income and Labour Dynamics in Australia (https://www.melbourneinstitute.com/hilda/), the Swiss Household Panel and the German Socio-Economic Panel (https://www.diw.de/en/soep), the OECD Employment database (http://oe.cd/1Dp), the OECD Product Market Regulation database (http://oe.cd/1Dq) and the OECD Economic Outlook database (http://oe.cd/1Dr). 
53. By contrast, ALMP spending shows little interaction with product market reforms (approximated by ETCR). This finding may reflect that the increase in job-finding probabilities resulting from making product markets more flexible primarily comes from people moving into employment from economic inactivity rather than unemployment, as reported above.

\subsection{Coordination of wage bargaining and the chances of becoming employed}

54. Compared with tighter coordination, decentralised wage bargaining systems should make it easier for firms to hire workers at wages that correspond to the marginal productivity of the new job opportunities generated by reforms that instil more product market competition. The data confirm this pattern: The generally positive effect of product market reforms on the chances of becoming employed is larger at low levels of coordination in wage bargaining (Figure 9).

Figure 9. The positive effect of more decentralised wage bargaining on the hiring benefits from product market reforms

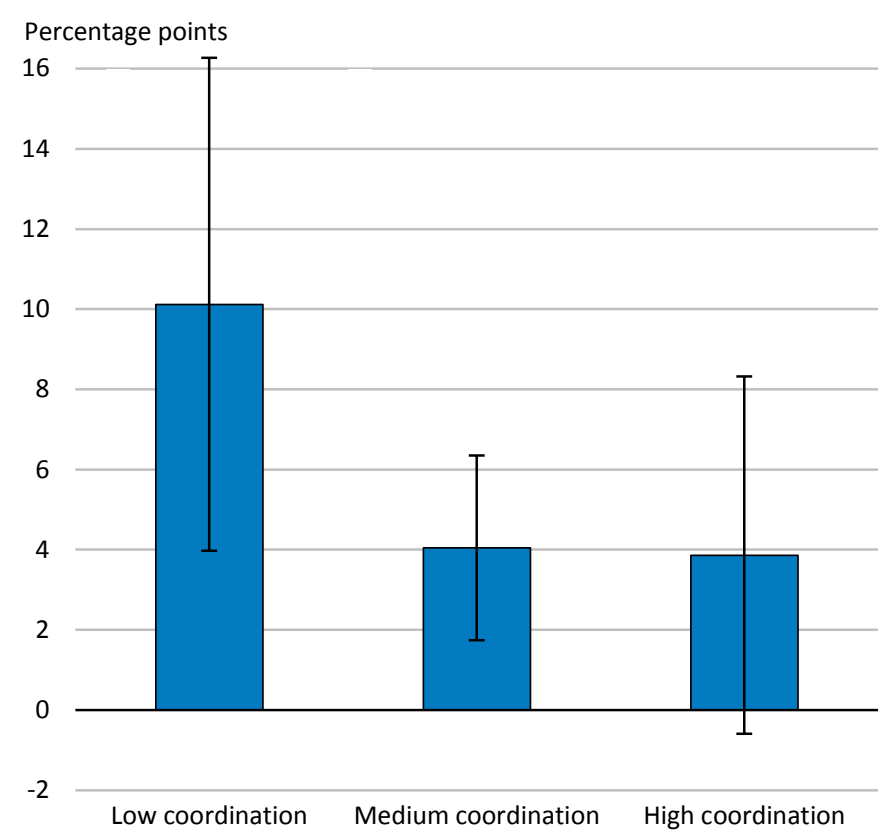

Note: The blue bars reflect the impact of a typical network industry reform, obtained by multiplying the coefficients from the estimation results (not shown here but available on request) by the five-year change of ETCR (see Table 3). The thin lines show $90 \%$ confidence intervals. Coordination is measured by the indicator of the degree of wage-setting coordination in the database on institutional characteristics of trade unions, wage setting, state intervention and social pacts (ICTWSS; see Visser, 2015). This indicator, which takes values ranging from 1 to 5 , evaluates the degree, rather than the legal type, of coordination (Kenworthy, 2001; Visser, 2015). Medium coordination here regroups countries and years where the indicator takes values between 2 and 4 . The estimations are carried out on micro-level data covering 26 OECD countries over 1994-2012 (see Table 1 for details on the sample coverage).

Source: Authors' calculations using the European Community Household Panel (http://bit.ly/2gjPZ10), the EU Survey of Income and Living Conditions (http://bit.ly/2flqXWd), the British Household Panel Survey (https://www.iser.essex.ac.uk/bhps), the Survey of Household, Income and Labour Dynamics in Australia (https://www.melbourneinstitute.com/hilda/), the Swiss Household Panel and the German Socio-Economic Panel (https://www.diw.de/en/soep), the OECD Employment database (http://oe.cd/1Dp), the OECD Product Market Regulation database (http://oe.cd/1Dq), the OECD Economic Outlook database (http://oe.cd/1Dr) and the ICTWSS database

(http://uva-aias.net/en/ictwss). 


\subsection{Coordination of wage bargaining and the chances of becoming jobless}

55. Intermediate levels of coordination in wage bargaining run the risk that wages may become loosely linked to micro and macro conditions (Calmfors and Driffill, 1988). Such possible wage mismatches may put firms in the situation of using the firing margin more actively than wage adjustments when coordination occurs at the intermediate level, especially when more flexible EPL lowers the cost of firing. The data suggest that this effect is at work, since more flexible EPL for regular contracts is associated with higher probabilities of becoming jobless in countries with intermediate levels of coordination (Figure 10). By contrast, low and high levels of coordination are associated with a decrease in the probability of becoming jobless.

Figure 10. Effect of more flexible EPL for regular contracts on the probability of becoming jobless depending on the degree of wage coordination

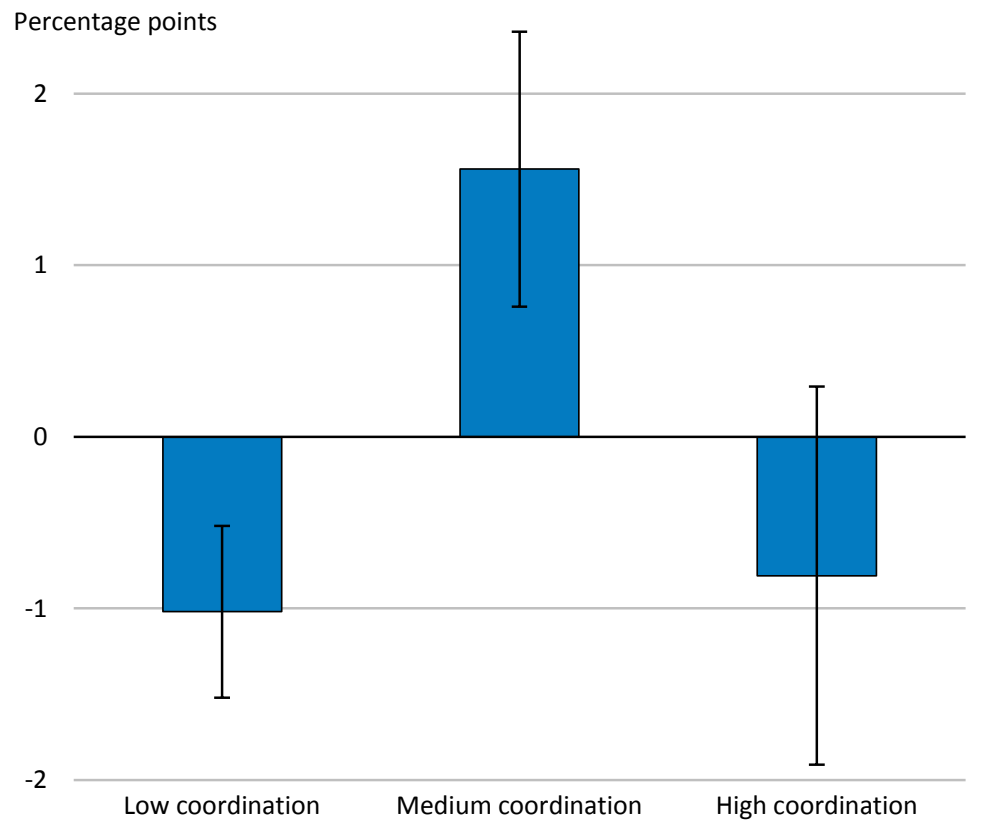

Note: The blue bars reflect the impact of a typical employment protection reform for regular contracts, obtained by multiplying the coefficients from the estimation results (not shown here but available on request) by the five-year change of EPL-R (see Table 3 ). The thin lines show $90 \%$ confidence intervals. Coordination is measured by the indicator of the degree of wage-setting coordination in the database on institutional characteristics of trade unions, wage setting, state intervention and social pacts (ICTWSS; see Visser, 2015). This indicator, which takes values ranging from 1 to 5 , evaluates the degree, rather than the legal type, of coordination (Kenworthy, 2001; Visser, 2015). Medium coordination here regroups countries and years where the indicator takes values between 2 and 4. The estimations are carried out on micro-level data covering 26 OECD countries over 1994-2012 (see Table 1 for details on the sample coverage).

Source: Authors' calculations using the European Community Household Panel (http://bit.ly/2gjPZ10), the EU Survey of Income and Living Conditions (http://bit.ly/2flqXWd), the British Household Panel Survey (https://www.iser.essex.ac.uk/bhps), the Survey of Household, Income and Labour Dynamics in Australia (https://www.melbourneinstitute.com/hilda/), the Swiss Household Panel and the German Socio-Economic Panel (https://www.diw.de/en/soep), the OECD Employment database (http://oe.cd/1Dp), the OECD Product Market Regulation database (http://oe.cd/1Dq), the OECD Economic Outlook database (http://oe.cd/1Dr) and the ICTWSS database (http://uva-aias.net/en/ictwss).

\subsection{The interaction of flexible labour and product markets and the chances of becoming jobless}

56. Reforms increasing the flexibility of labour or product markets may have differential effects depending on the flexibility of other markets. Reforms that boost product market competition could entail greater costs for workers in more rigid labour markets. Figure 11 confirms this idea: After a reform that increases competition in product markets, measured by a typical ETCR reform, the probability of losing a 
job rises when the employment protection for regular workers is very tight. Recent labour market reforms imply, however, that no OECD country is currently above the 3.7 EPL-R threshold above which ETCR reform exacerbates the risk of becoming jobless in a statistically significant way.

Figure 11. Effect of a typical ETCR reform on the probability of becoming jobless depending on the flexibility of labour markets

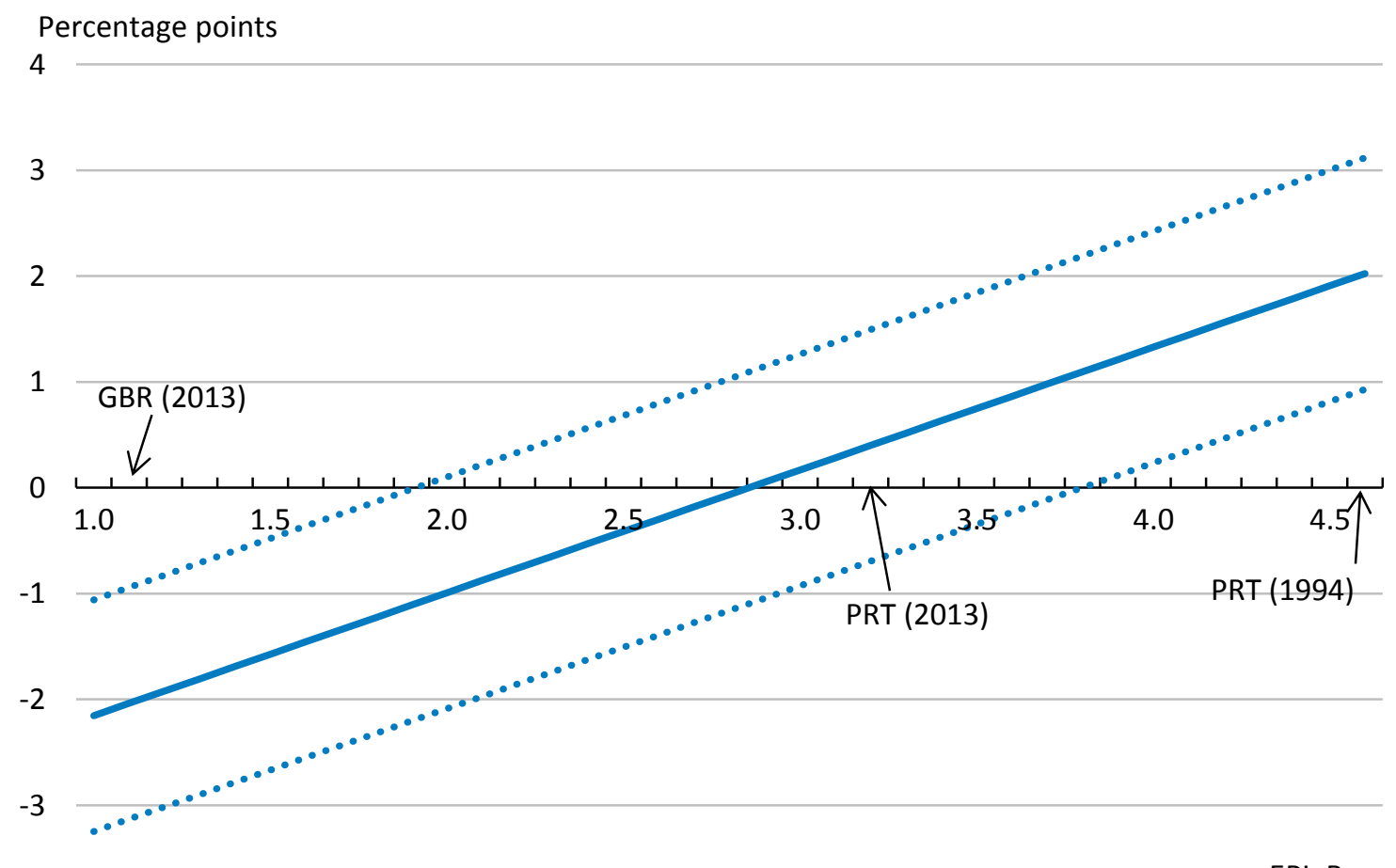

$-4$

EPL-R

Note: The line plots the effect of a typical product market reform, obtained by multiplying the coefficients from the estimation results (not shown here but available on request) by the typical five-year change of ETCR (see Table 3) for different values of EPL-R in the sample. The dotted lines show $90 \%$ confidence intervals. The estimations are carried out on micro-level data covering 26 OECD countries over 1994-2012 (see Table 1 for details on the sample coverage).

Source: Authors' calculations using the European Community Household Panel (http://bit.ly/2gjPZ10), the EU Survey of Income and Living Conditions (http://bit.ly/2flqXWd), the British Household Panel Survey (https://www.iser.essex.ac.uk/bhps), the Survey of Household, Income and Labour Dynamics in Australia (https://www.melbourneinstitute.com/hilda/), the Swiss Household Panel and the German Socio-Economic Panel (https://www.diw.de/en/soep), the OECD Employment database (http://oe.cd/1Dp), the OECD Product Market Regulation database (http://oe.cd/1Dq) and the OECD Economic Outlook database (http://oe.cd/1Dr).

57. Conversely, when regular-contract protection is very flexible, the probability of losing a job diminishes following ETCR reform. OECD EPL-R indicators for Chile, New Zealand, the United Kingdom and the United States are below the 1.9 cut-off point below which ETCR reform is estimated to reduce the risk of becoming jobless in a statistically significant way. These conclusions indicate that product market reforms reduce the risk of becoming jobless when employment protection for regular workers is highly flexible but not in other settings. 


\section{Effects across different population groups}

58. The estimated effects described in Section 4 average over different population groups, which reforms can affect differently. This section looks at how gender, age, education and income influence the effect of reforms on transition probabilities into and out of employment. The results presented are from estimations of Equation 10. They are similar when policy variables are simultaneously interacted with population groups defined along the four dimensions, rather than with each definition of population group one at a time. Further robustness checks that include country-year fixed effects (Equation 11) yield estimates for differential effects across groups that are also broadly similar.

\subsection{Gender}

59. The average favourable effect of easing product market regulation on the chance of becoming employed seems to come primarily from effects on women (Figure 12). A typical reform increases the chance that a woman becomes employed by 3 percentage points, which is to be put against an average chance of becoming employed for women of about $25 \%$. The effect is stronger for women, even though the transition rate from joblessness to employment is much larger for men. The difference in the effects between men and women remains unchanged when country-year fixed effects are introduced. By contrast, employment protection reforms have no discernible influence on the job-finding rate of either men or women.

60. The positive effect of less product market regulation on women's chances to become employed may be related to the observation made above that the positive effect stems primarily from transitions into employment from economic inactivity rather than unemployment. By boosting real wages, product market reforms may draw women into employment for whom work was previously marginally unattractive. An additional potential explanation is that the pool of economically inactive women may contain significantly better suited matches for the jobs created by more flexible product markets than the pool of economically inactive men. 
Figure 12. Effect of typical flexibility-enhancing reforms on job-finding chances for men and women

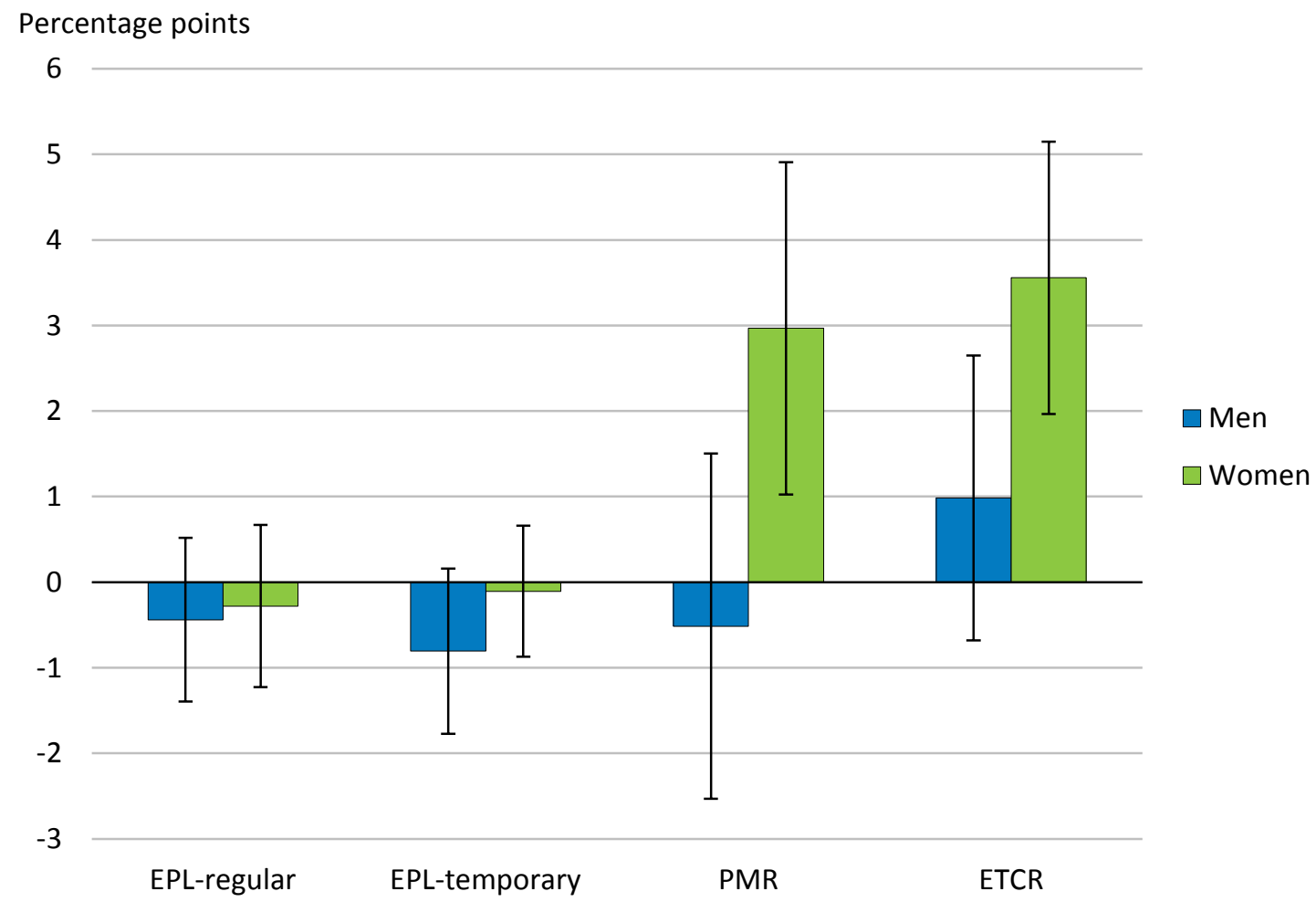

Note: The bars indicate the estimated effect of a typical flexibility-enhancing reform, defined as the average five-year change over reform episodes (see Table 3). The thin lines show $90 \%$ confidence intervals. The estimations are carried out on micro-level data covering 26 OECD countries over 1994-2012 (see Table 1 for details on the sample coverage).

Source: Authors' calculations using the European Community Household Panel (http://bit.ly/2gjPZ10), the EU Survey of Income and Living Conditions (http://bit.ly/2flqXWd), the British Household Panel Survey (https://www.iser.essex.ac.uk/bhps), the Survey of Household, Income and Labour Dynamics in Australia (https://www.melbourneinstitute.com/hilda/), the Swiss Household Panel and the German Socio-Economic Panel (https://www.diw.de/en/soep), the OECD Employment database (http://oe.cd/1Dp), the OECD Product Market Regulation database (http://oe.cd/1Dq) and the OECD Economic Outlook database (http://oe.cd/1Dr).

61. The absence of average effects of flexibility-enhancing reforms on the risk of becoming jobless also broadly applies to men and women (Figure 13). The effect that is visible for men when using the PMR indicator is not replicated when using the ETCR indicator. These estimation results are very similar when specifications with country-year fixed effects are used. 
ECO/WKP(2016)72

Figure 13. Effect of typical flexibility-enhancing reforms on the risk of becoming jobless for men and women Percentage points

2

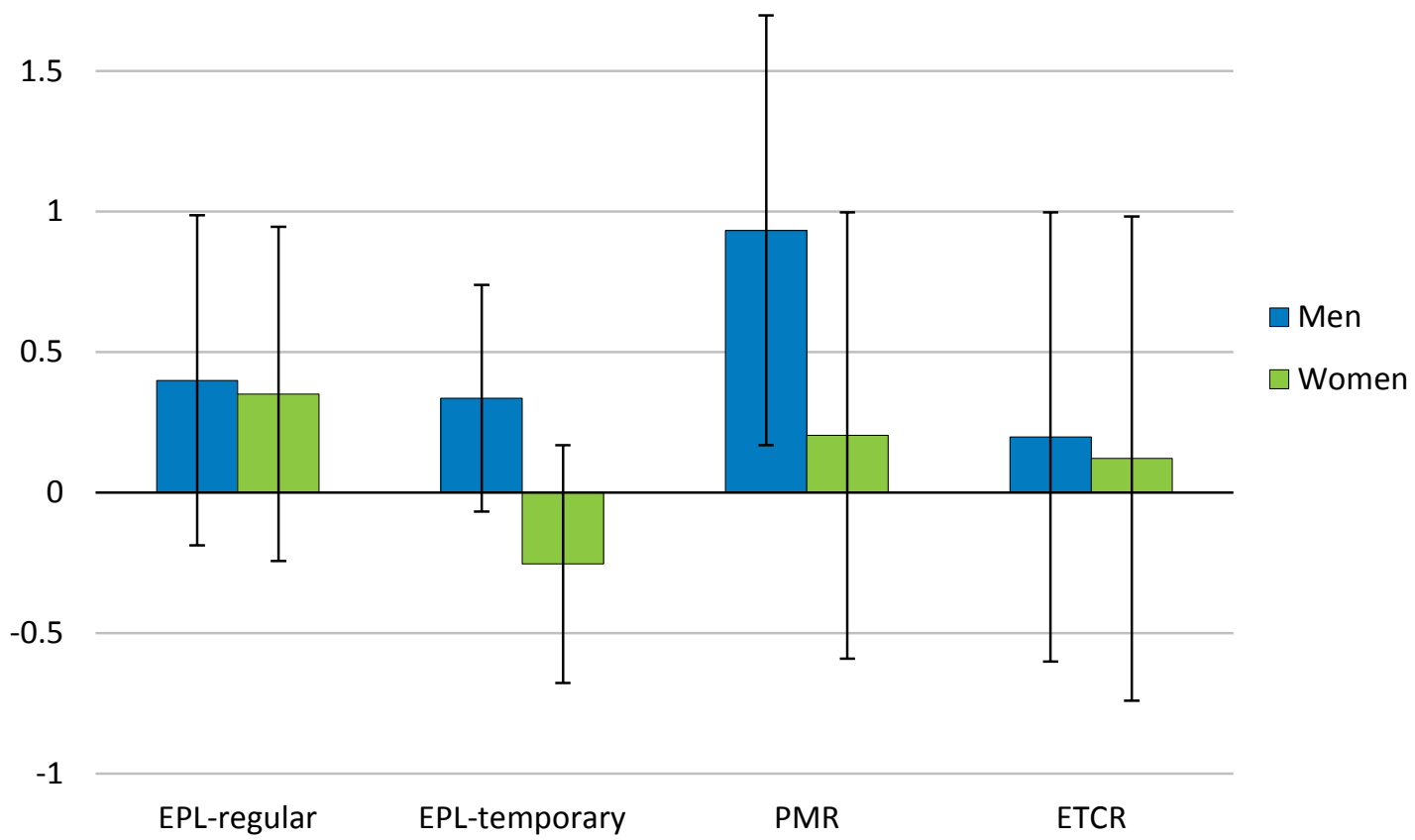

Note: The bars indicate the estimated effect of a typical flexibility-enhancing reform, defined as the average five-year change over reform episodes (see Table 3). The thin lines show 90\% confidence intervals. The estimations are carried out on micro-level data covering 26 OECD countries over 1994-2012 (see Table 1 for details on the sample coverage).

Source: Authors' calculations using the European Community Household Panel (http://bit.ly/2gjPZ10), the EU Survey of Income and Living Conditions (http://bit.ly/2flqXWd), the British Household Panel Survey (https://www.iser.essex.ac.uk/bhps), the Survey of Household, Income and Labour Dynamics in Australia (https://www.melbourneinstitute.com/hilda/), the Swiss Household Panel and the German Socio-Economic Panel (https://www.diw.de/en/soep), the OECD Employment database (http://oe.cd/1Dp), the OECD Product Market Regulation database (http://oe.cd/1Dq) and the OECD Economic Outlook database (http://oe.cd/1Dr). 


\subsection{Age}

62. The effect of flexibility-enhancing reforms on transition rates appears to vary with age in three cases. The generally positive effect of making product markets more flexible, reflected in a reduction of the PMR indicator, on the chance of becoming employed is stronger for younger people (Figure 14). After a typical economy-wide product market reform, the chance to become employed increases by 3 percentage points for the 25-34-year-olds. The effect becomes statistically insignificant at age 45 . The pattern for network industry reforms (defined by a decline in the ETCR) is similar, with young workers benefiting more than older workers. The results for PMR and ETCR on heterogeneity by age survive the inclusion of country-year fixed effects.

Figure 14. Effect of a typical product market reform on job-finding chances by age

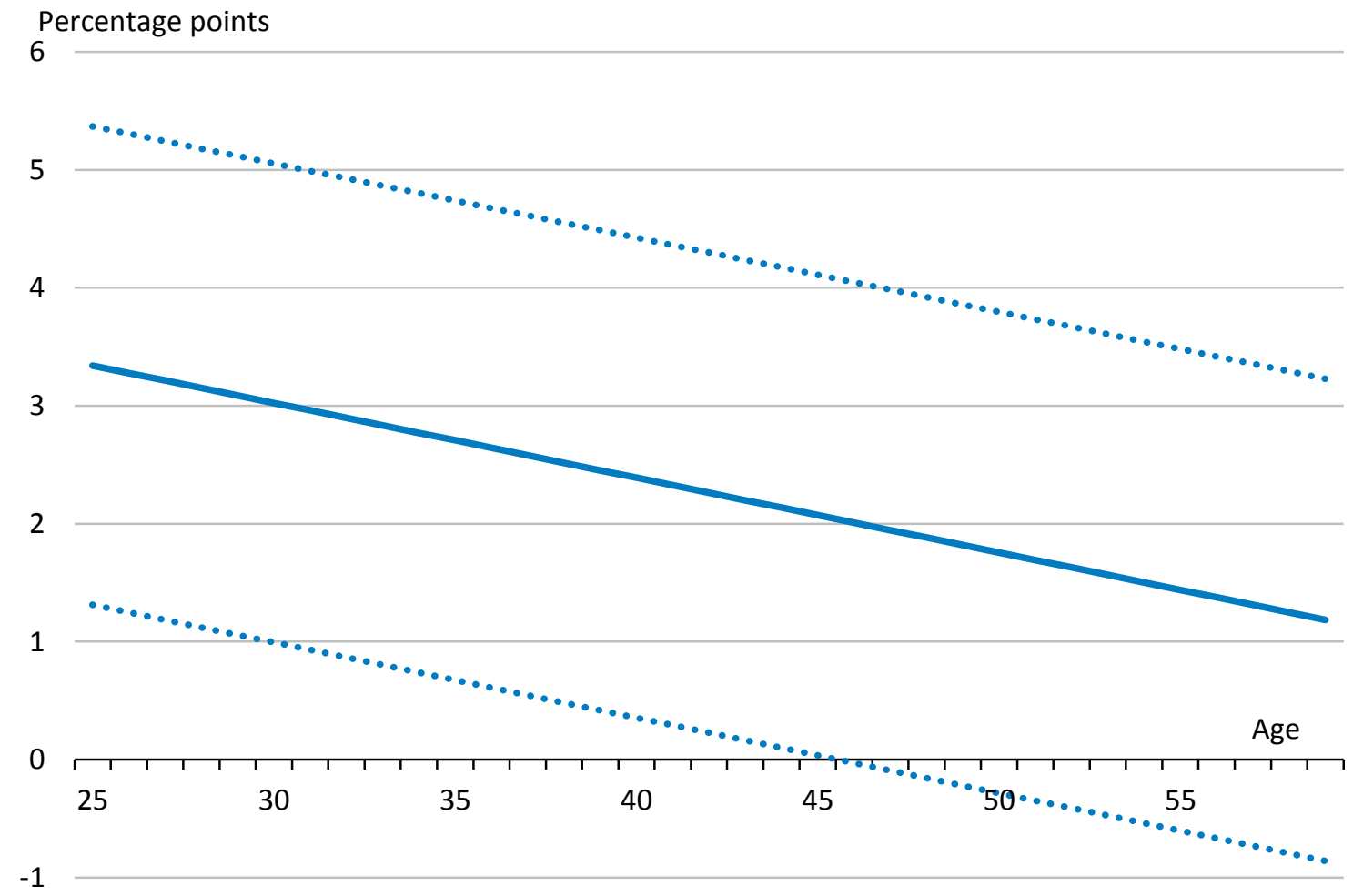

Note: The line plots the economy-wide effect of a typical product market reform, measured as a 0.34 fall in the PMR indicator (see Table 3). The dotted lines surround the $90 \%$ confidence interval. The estimations are carried out on micro-level data covering 26 OECD countries over 1994-2012 (see Table 1 for details on the sample coverage).

Source: Authors' calculations using the European Community Household Panel (http://bit.ly/2gjPZ1o), the EU Survey of Income and Living Conditions (http://bit.ly/2flqXWd), the British Household Panel Survey (https://www.iser.essex.ac.uk/bhps), the Survey of Household, Income and Labour Dynamics in Australia (https://www.melbourneinstitute.com/hilda/), the Swiss Household Panel and the German Socio-Economic Panel (https://www.diw.de/en/soep), the OECD Employment database (http://oe.cd/1Dp), the OECD Product Market Regulation database (http://oe.cd/1Dq) and the OECD Economic Outlook database (http://oe.cd/1Dr).

63. As regards job separations, making regular EPL more flexible increases the risk of becoming jobless in a statistically significant manner for those in their upper $20 \mathrm{~s}$, while there is no average effect (Section 4). However, the estimated effect on the young is small (two-thirds of a percentage point) and only statistically significant at the $10 \%$ level. 


\subsection{Education}

64. Product market reforms raise the chance of finding a job by similar amounts for all education groups (Figure 15). Differences across groups are mostly not statistically significant, in specifications with and without country-year fixed effects. This is despite the transition rate from joblessness to employment being twice as high for those with more than a high school degree than for those without one. Reforms of job protection exhibit no systematic relationship with the chance of becoming employed across different education groups.

\section{Figure 15. Effect of a typical product market reform on the chance of finding a job by skill level}

\section{Percentage points}

6

5

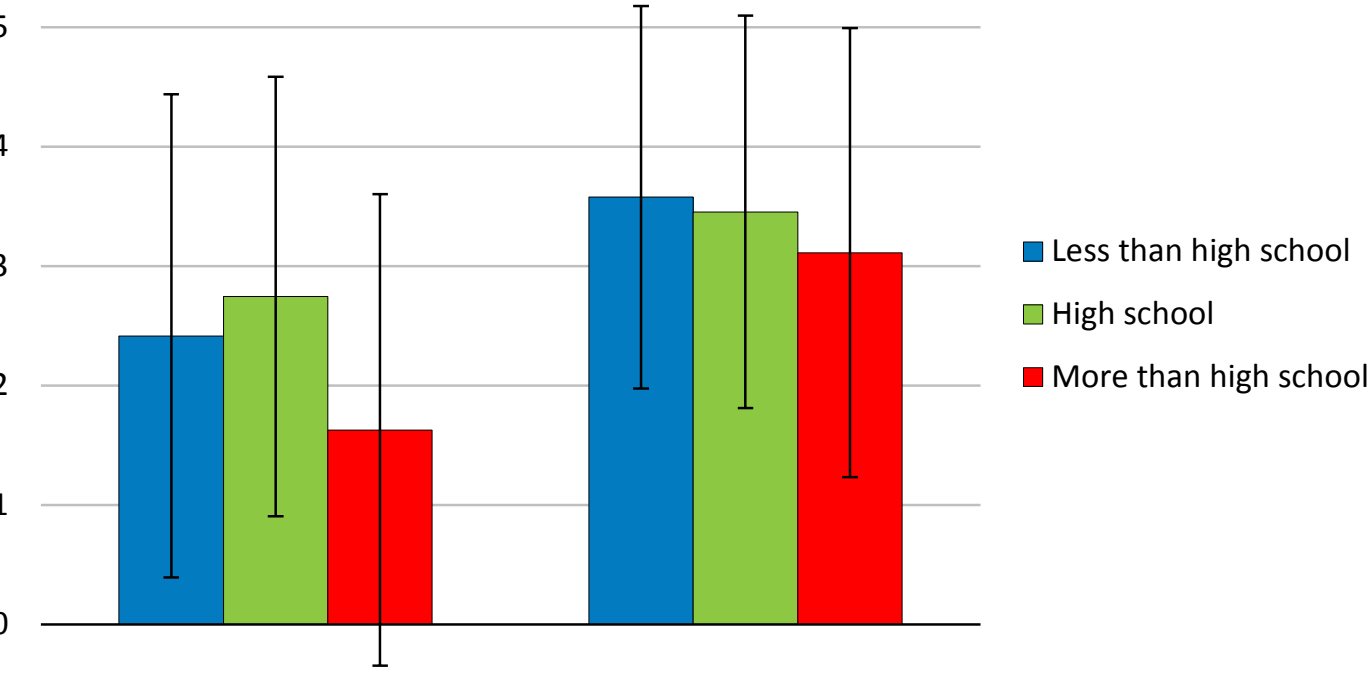

$-1$

PMR

ETCR

Note: The bars indicate the estimated effect of a typical flexibility-enhancing reform, defined as the average five-year change over reform episodes (see Table 3). The thin lines show $90 \%$ confidence intervals. The estimations are carried out on micro-level data covering 26 OECD countries over 1994-2012 (see Table 1 for details on the sample coverage).

Source: Authors' calculations using the European Community Household Panel (http://bit.ly/2gjPZ10), the EU Survey of Income and Living Conditions (http://bit.ly/2flqXWd), the British Household Panel Survey (https://www.iser.essex.ac.uk/bhps), the Survey of Household, Income and Labour Dynamics in Australia (https://www.melbourneinstitute.com/hilda/), the Swiss Household Panel and the German Socio-Economic Panel (https://www.diw.de/en/soep), the OECD Employment database (http://oe.cd/1Dp), the OECD Product Market Regulation database (http://oe.cd/1Dq) and the OECD Economic Outlook database (http://oe.cd/1Dr).

65. Product market reforms increase the risk of job loss for low-educated people (Figure 16), a group for which the transition rate from employment to joblessness is already nearly twice as high as for higheducation people. The effects for the other two education groups are not statistically significant. Specifications with country-year fixed effects tend to show stronger effects for the low-educated as well. Reforms of job protection exhibit again no systematic relationship with the risk of job loss across different education groups. 
Figure 16. Effect of a typical product market reform on the risk of becoming jobless by skill level Percentage points

3

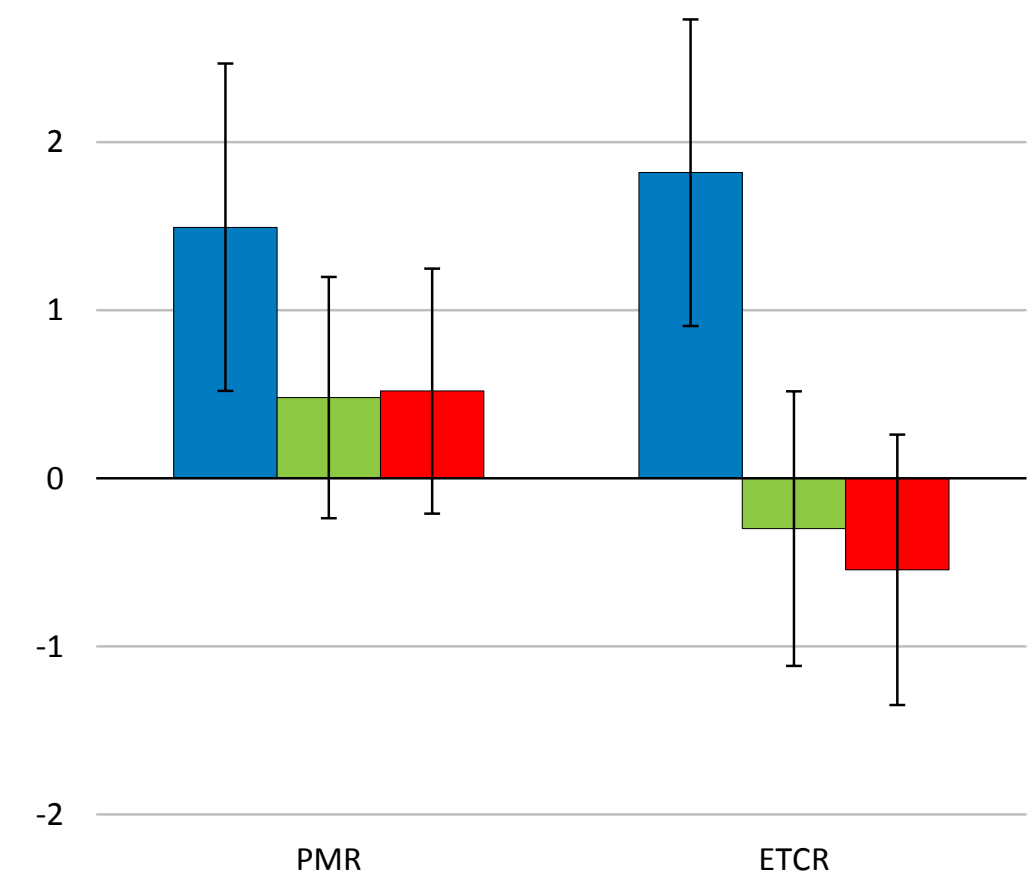

$\square$ Less than high school

$\square$ High school

More than high school

ETCR

Note: The bars indicate the estimated effect of a typical flexibility-enhancing reform, defined as the average five-year change over reform episodes (see Table 3). The thin lines show $90 \%$ confidence intervals. The estimations are carried out on micro-level data covering 26 OECD countries over 1994-2012 (see Table 1 for details on the sample coverage).

Source: Authors' calculations using the European Community Household Panel (http://bit.ly/2gjPZ10), the EU Survey of Income and Living Conditions (http://bit.ly/2flgXWd), the British Household Panel Survey (https://www.iser.essex.ac.uk/bhps), the Survey of Household, Income and Labour Dynamics in Australia (https://www.melbourneinstitute.com/hilda/), the Swiss Household Panel and the German Socio-Economic Panel (https://www.diw.de/en/soep), the OECD Employment database (http://oe.cd/1Dp), the OECD Product Market Regulation database (http://oe.cd/1Dq) and the OECD Economic Outlook database (http://oe.cd/1Dr). 
66. Taken together, the estimated effects of product market reforms, measured by ETCR, on the risk of becoming jobless and the probability of getting a job imply higher employment for all groups, including low-educated workers (see Figure 17 for the results of simulations using Equation 7). The results have been checked for robustness by using the PMR rather than the ETCR indicator and by directly estimating employment effects of reforms by group. In these checks, for each group, product market reforms are found to either improve employment rates or leave them broadly unchanged. These checks also suggest that the employment gains from product market reforms are largest for middle-educated workers, as Gal and Theising (2015) found.

Figure 17. Implied employment rate effects of product market reforms Implied steady-state employment rates before and after a typical product market reform

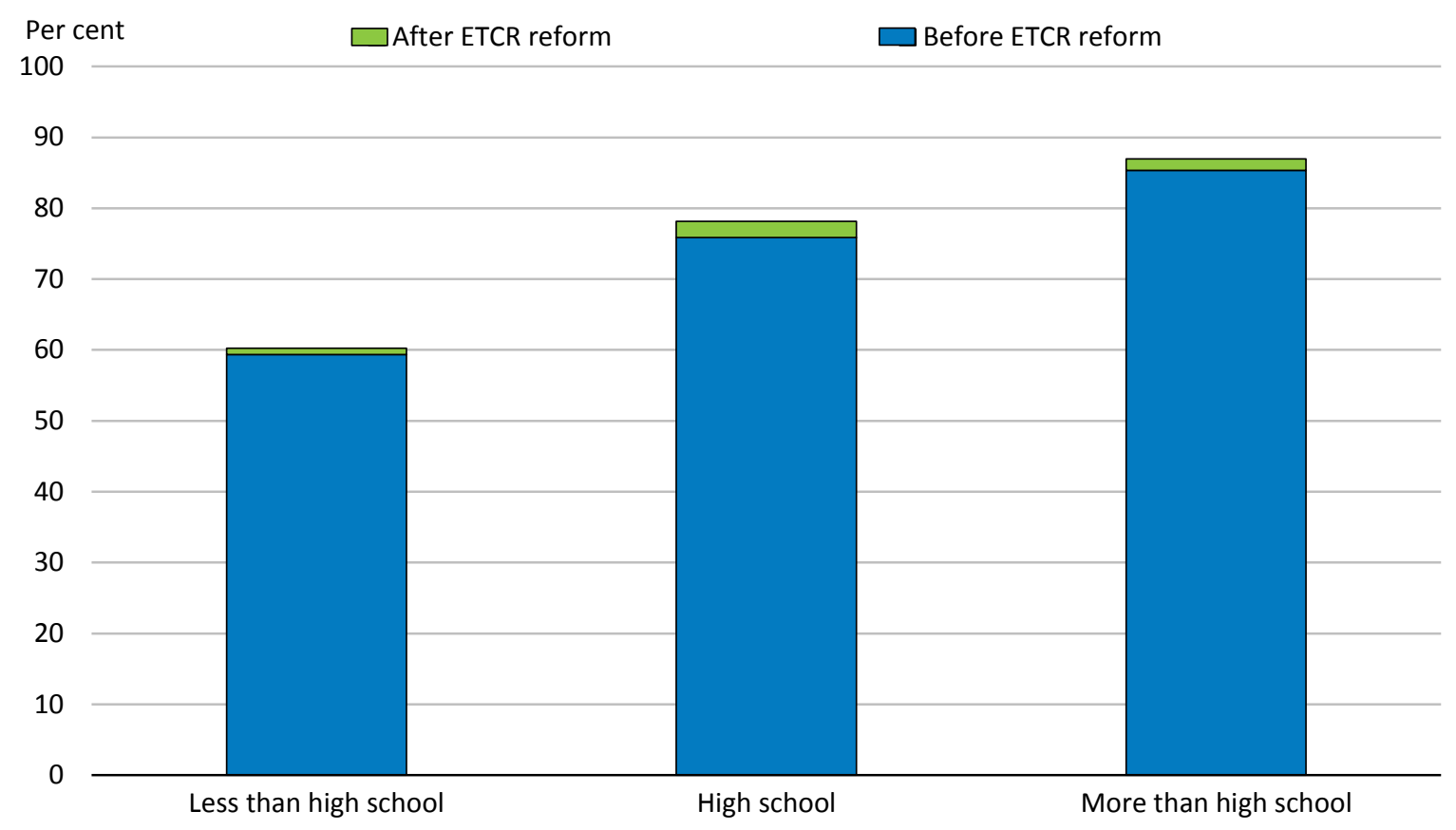

Note: The bars indicate the simulated effect of a typical product market reform of network industries (measured as a 0.92 fall in the ETCR indicator) on steady-state aggregate employment rates associated with labour market transitions (see Box 1). The estimations are carried out on micro-level data covering 26 OECD countries over 1994-2012 (see Table 1 for details on the sample coverage).

Source: Authors' calculations using the European Community Household Panel (http://bit.ly/2gjPZ10), the EU Survey of Income and Living Conditions (http://bit.ly/2flqXWd), the British Household Panel Survey (https://www.iser.essex.ac.uk/bhps), the Survey of Household, Income and Labour Dynamics in Australia (https://www.melbourneinstitute.com/hilda/), the Swiss Household Panel and the German Socio-Economic Panel (https://www.diw.de/en/soep), the OECD Employment database (http://oe.cd/1Dp), the OECD Product Market Regulation database (http://oe.cd/1Dq) and the OECD Economic Outlook database (http://oe.cd/1Dr). 


\subsection{Income}

67. Product market reforms raise the chance of finding a job by similar amounts for all income groups (Figure 18). The increase in job-finding chances is of greater statistical significance for the first income quartile than the other ones, but economically the coefficients are mostly comparable. The same holds for regressions with country-year fixed effects, in which coefficients for the four quartiles are not significantly different from each other. On average, the transition rate from joblessness to employment for the bottom quartile is only one third of that for the other quartiles. As with education, reforms of job protection exhibit no systematic relationship with the chance of becoming employed across different income groups.

\section{Figure 18. Effect of a typical product market reform on the chance of finding a job by income level}

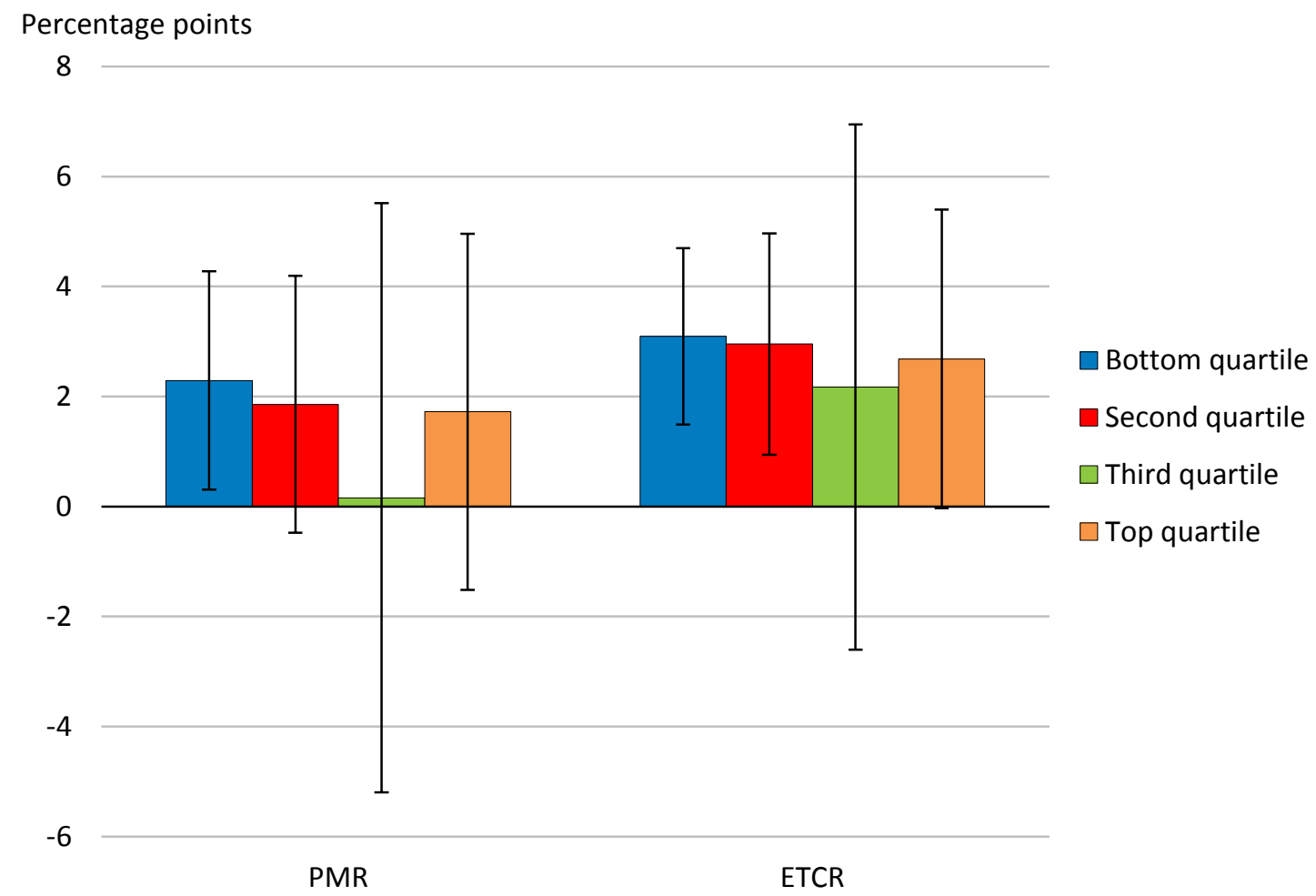

Note: The bars indicate the estimated effect of a typical flexibility-enhancing reform, defined as the average five-year change over reform episodes (see Table 3). The thin lines show $90 \%$ confidence intervals. The estimations are carried out on micro-level data covering 26 OECD countries over 1994-2012 (see Table 1 for details on the sample coverage).

Source: Authors' calculations using the European Community Household Panel (http://bit.ly/2gjPZ10), the EU Survey of Income and Living Conditions (http://bit.ly/2flqXWd), the British Household Panel Survey (https://www.iser.essex.ac.uk/bhps), the Survey of Household, Income and Labour Dynamics in Australia (https://www.melbourneinstitute.com/hilda/), the Swiss Household Panel and the German Socio-Economic Panel (https://www.diw.de/en/soep), the OECD Employment database (http://oe.cd/1Dp), the OECD Product Market Regulation database (http://oe.cd/1Dq) and the OECD Economic Outlook database (http://oe.cd/1Dr). 
68. Product market reforms increase the risk of becoming unemployed or inactive by significantly more for low-income people than for others (Figure 19). The effect is statistically insignificant for all income quartiles except the bottom one, for which it is strong. In specifications with country-year fixed effects, the coefficient for the bottom quartile is also much larger, in a statistically significant fashion, than for the other quartiles. The average transition rate from employment to joblessness is considerably higher for the bottom quartile. A typical product market reform of network industries raises the risk of job loss from $25 \%$ to $28 \%$ for this income group. This effect suggests that increasing product market competition involves more labour market churn particularly among low-productivity jobs. An explanation could be that stronger competition predominantly reallocates jobs that previously were only marginally profitable.

69. The estimated increase in the chance of finding a job is large enough to offset the rise in the risk of becoming jobless. Simulations using Equation 7 point to small employment gains for all groups following product market reforms.

Figure 19. Effect of a typical product market reform on the risk of becoming jobless by income level

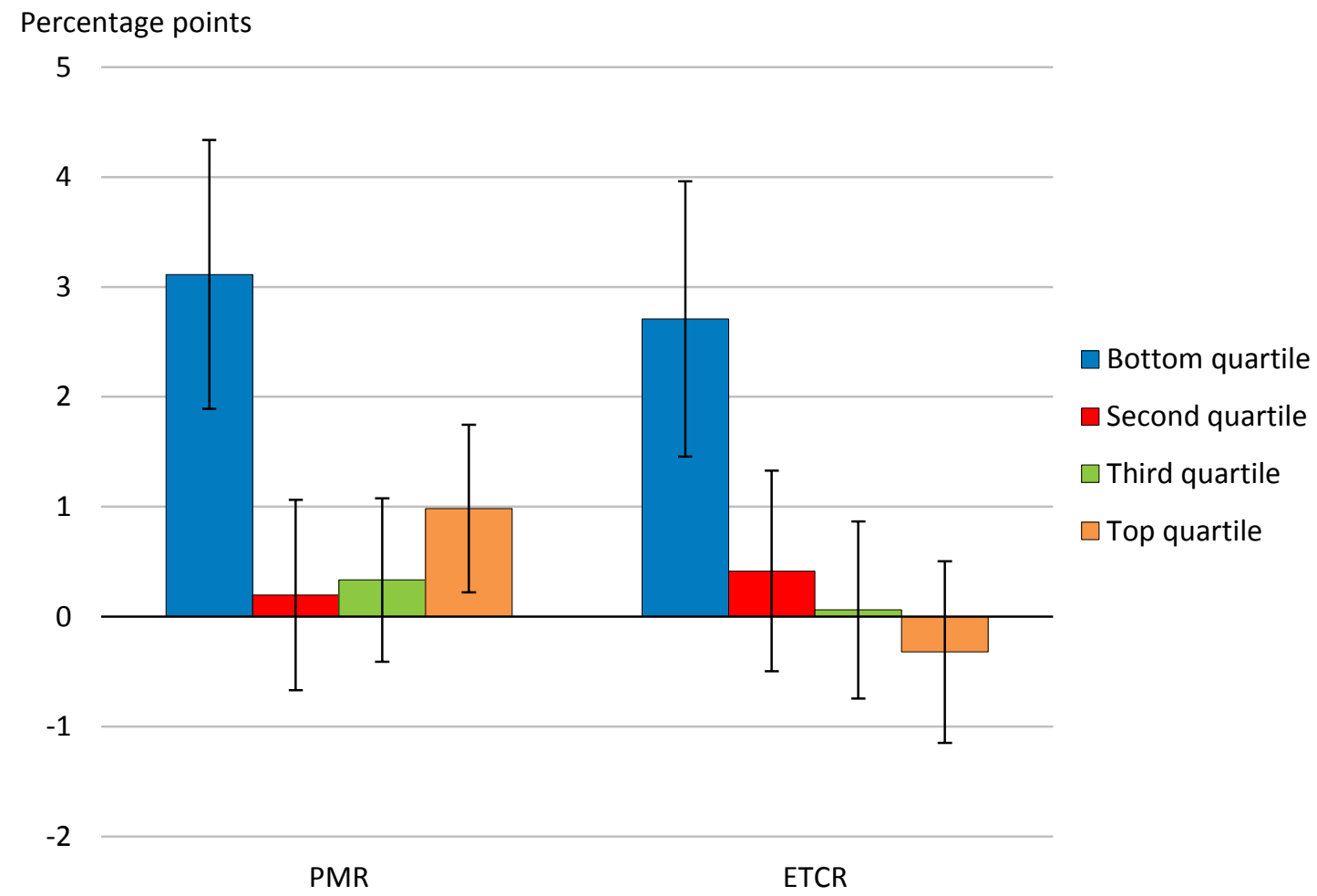

Note: The bars indicate the estimated effect of a typical flexibility-enhancing reform, defined as the average five-year change over reform episodes (see Table 3). The thin lines show 90\% confidence intervals. Quartiles are calculated over the previous year's average monthly labour income in months during which the individual worked. The estimations are carried out on micro-level data covering 26 OECD countries over 1994-2012 (see Table 1 for details on the sample coverage).

Source: Authors' calculations using the European Community Household Panel (http://bit.ly/2gjPZ10), the EU Survey of Income and Living Conditions (http://bit.ly/2flgXWd), the British Household Panel Survey (https://www.iser.essex.ac.uk/bhps), the Survey of Household, Income and Labour Dynamics in Australia (https://www.melbourneinstitute.com/hilda/), the Swiss Household Panel and the German Socio-Economic Panel (https://www.diw.de/en/soep), the OECD Employment database (http://oe.cd/1Dp), the OECD Product Market Regulation database (http://oe.cd/1Dq) and the OECD Economic Outlook database (http://oe.cd/1Dr). 


\section{Concluding remarks}

70. This paper underscores that flexibility-enhancing reforms, which generate aggregate benefits for the economy, can influence the stability of employment relationships. A general association between more flexibility and greater labour market churn is economically visible but not always statistically significant. The lack of systematic significance reflects that this link varies depending on framework conditions and across the population (Table 7).

71. In particular, making product markets more competitive raises the risk of job loss significantly more for people who are low-skilled or have low income, hence for those who already before reform are particularly vulnerable to becoming jobless. Low-skilled or low-income workers benefit, however, from the higher job-finding chances that product market reforms bring, so that their employment prospects improve, although only slightly. Given the high negative impact of low income and firings on well-being, these findings raise questions about the effect of flexibility-enhancing reforms on vulnerable groups in society. Semi-aggregated evidence suggests that higher labour market turnover and slightly better employment prospects should imply lower unemployment duration and higher levels of well-being (Hijzen and Menyhert, 2015). Broader cross-country micro panel data with information on well-being would be very useful to directly explore this important question in future research. Future research could also investigate the extent to which other characteristics, such as immigration status, influence reform effects. 
ECO/WKP(2016)72

Table 7. Estimated effects of more flexible product and labour market regulation

Summary of results, percentage points for typical reforms

Long-term effects of reform on:

Effects of reduced:

\begin{tabular}{|c|c|c|c|c|}
\hline & \multicolumn{2}{|c|}{ Product market regulation } & \multirow{2}{*}{$\begin{array}{c}\begin{array}{c}\text { Protection of } \\
\text { regular } \\
\text { contracts }\end{array} \\
E P L-R^{3} \\
\end{array}$} & \multirow{2}{*}{$\begin{array}{c}\begin{array}{c}\text { Protection of } \\
\text { temporary } \\
\text { contracts }\end{array} \\
E P L-T^{3} \\
\end{array}$} \\
\hline & $\mathrm{PMR}^{1}$ & $\mathrm{ETCR}^{2}$ & & \\
\hline \multicolumn{5}{|l|}{ Probability of becoming jobless } \\
\hline Probability of becoming employed & $2.0^{*}$ & $3.0^{* * *}$ & & \\
\hline Job-finding probability in the presence of high ALMP ${ }^{4}$ & & & $5.3^{\star \star \star}$ & \\
\hline Job-finding probability under centralised bargaining & 3.8 & & & \\
\hline intermediate bargaining & $4.02^{\star \star}$ & & & \\
\hline decentralised bargaining & $10.1^{* * *}$ & & & \\
\hline Risk of becoming jobless with centralised bargaining & & & -.08 & \\
\hline intermediate bargaining & & & $1.65^{\star *}$ & \\
\hline decentralised bargaining & & & $-1.0^{* *}$ & \\
\hline Risk of becoming jobless with very flexible EPL- $R^{5}$ & $-1.9^{\star *}$ & & & \\
\hline \multicolumn{5}{|l|}{ Men's job-finding probability } \\
\hline Women's job-finding probability & $2.9^{* *}$ & $3.2^{* * *}$ & & \\
\hline Men's risk of becoming jobless & $0.9^{*}$ & & & \\
\hline \multicolumn{5}{|l|}{ Women's risk of becoming jobless } \\
\hline Job-finding probability of workers aged 27 & $3.1^{\star *}$ & & & \\
\hline Risk of becoming jobless of workers aged 27 & & & $0.2^{*}$ & \\
\hline Job-finding probability for low-educated workers & $2.1^{*}$ & $3.5^{\star \star \star}$ & & \\
\hline Job-finding probability for middle-educated workers & $2.5^{\star \star}$ & $3.4^{\star \star \star}$ & & \\
\hline Job-finding probability for high-educated workers & & $3.0^{\star *}$ & & \\
\hline Risk of becoming jobless for low-educated workers & $1.4^{*}$ & $1.9^{* *}$ & & \\
\hline \multicolumn{5}{|l|}{ Risk of becoming jobless for middle-educated workers } \\
\hline \multicolumn{5}{|l|}{ Risk of becoming jobless for high-educated workers } \\
\hline Job-finding probability for low-income workers & $2.0^{*}$ & $2.5^{\star *}$ & & \\
\hline \multicolumn{5}{|l|}{ Job-finding probability for high-income workers } \\
\hline Risk of becoming jobless for low-income workers & $3.0^{\star * \star}$ & $2.8^{\star \star \star}$ & & \\
\hline Risk of becoming jobless for high-income workers & $1.0^{*}$ & & & \\
\hline
\end{tabular}

Notes: ETCR stands for the OECD index of regulation in energy, transport and communication. PMR denotes the OECD indicator of product market regulation. The estimations are carried out on micro-level data covering 26 OECD countries over 1994-2012 (see Table 1 for details on the sample coverage). Three, two and one star denote $99 \%, 95 \%$ and $90 \%$ confidence levels.

1. PMR stands for the OECD indicator of product market regulation.

2. ETCR stands for the OECD index of regulation in energy, transport and communication.

3. EPL-R and EPL-T respectively denote the OECD measures of employment protection for regular and temporary contracts.

4. High ALMP means three times mean spending per person unemployed.

5. Very flexible EPL for regular contracts means an EPL-R index of 1.2.

Source: Authors' calculations using the European Community Household Panel (http://bit.ly/2gjPZ10), the EU Survey of Income and Living Conditions (http://bit.ly/2flqXWd), the British Household Panel Survey (https://www.iser.essex.ac.uk/bhps), the Survey of Household, Income and Labour Dynamics in Australia (https://www.melbourneinstitute.com/hilda/), the Swiss Household Panel and the German Socio-Economic Panel (https://www.diw.de/en/soep), the OECD Employment database (http://oe.cd/1Dp), the OECD Product Market Regulation database (http://oe.cd/1Dq), the OECD Economic Outlook database (http://oe.cd/1Dr) and the ICTWSS database (http://uva-aias.net/en/ictwss). 


\section{REFERENCES}

Adema, W., P. Fron and M. Ladaique (2011), "Is the European Welfare State Really More Expensive?", OECD Social, Employment and Migration Working Papers, No. 124, OECD Publishing, Paris.

Alesina, A., S. Ardagna, G. Nicoletti and F. Schiantarelli (2005), "Regulation and Investment", Journal of the European Economic Association, 3(4), pp. 791-825.

Aparicio-Fenoll, A. (2015), "The Effect of Product-Market Competition on Job Security", Labour Economics, 35, pp. 145-159.

Bassanini, A. and R. Duval (2006), "Employment Patterns in OECD Countries: Reassessing the Role of Policies and Institutions", OECD Economics Department Working Papers, No. 486, OECD Publishing, Paris.

Bassanini, A., and R. Duval (2009), "Unemployment, Institutions, and Reform Complementarities: ReAssessing the Aggregate Evidence for OECD Countries", Oxford Review of Economic Policy, 25(1), pp. 40-59.

Bassanini, A. and A. Garnero (2013), "Dismissal Protection and Worker Flows in OECD Countries: Evidence from Cross-Country/Cross-Industry Data", Labour Economics, 21, pp. 25-41.

Bassanini, A., A. Garnero, P. Marianna and S. Martin (2010), "Institutional Determinants of Worker Flows: A Cross-Country/Cross-Industry Approach", OECD Social, Employment and Migration Working Papers, No. 107, OECD Publishing, Paris.

Bassanini, A. (2015), “A Bitter Medicine? Short-Term Employment Impact of Deregulation in Network Industries", IZA Discussion Papers, No. 9187.

Behagel, L., B. Crépon and B. Sédillot (2008), "The Perverse Effects of Partial Employment Protection Reform: The Case of French Older Workers”, Journal of Public Economics, 92(3-4), pp. 696-721.

Von Below, D. and P. Thoursie (2010), "Last in, First out? Estimating the Effect of Seniority Rules in Sweden”, Labour Economics, 17, pp. 987-997.

Boarini, R., M. Comola, C. Smith, R. Manchin and F. de Keulenaer (2012), "What Makes for a Better Life? The Determinants of Subjective Well-Being in OECD Countries - Evidence from the Gallup World Poll”, OECD Statistics Working Papers, 2012/03, OECD Publishing, Paris.

Boeri, T., P. Cahuc and A. Zylberberg (2015), "The Costs of Flexibility-Enhancing Structural Reforms: A Literature Review", OECD Economics Department Working Papers, No. 1227, OECD Publishing, Paris. 
Boeri, T. and P. Garibaldi (2007), “Two Tier Reforms of Employment Protection: A Honeymoon Effect?”, Economic Journal, 117(521), pp. 357-385.

Boeri, T. and J. Jimeno (2005), "The Effects of Employment Protection: Learning from Variable Enforcement", European Economic Review, 49(8), pp. 2057-2077.

Bouis, R., O. Causa, L. Demmou, R. Duval and A. Zdzienicka (2012), "The Short-Term Effects of Structural Reforms: An Empirical Analysis", OECD Economics Department Working Papers, No. 949, OECD Publishing, Paris.

Causa, O., N. Ruiz and M. Hermansen (2016), "The Distributional Impact of Pro-Growth Reforms", OECD Economics Department Working Papers, No. 1342, OECD Publishing, Paris.

Clark, A. and A. Oswald (1994), "Unhappiness and Unemployment", Economic Journal, 104(424), pp. 648-659.

Cournède, B., O. Denk, P. Garda and P. Hoeller (2016), "Enhancing Economic Flexibility: What Is in It for Workers?", OECD Economic Policy Papers, No. 19, OECD Publishing, Paris.

Crépon, B., E. Duflo, M. Gurgand, R. Rathelot and P. Zamora (2013), "Do Labor Market Policies Have Displacement Effects? Evidence from a Clustered Randomized Experiment", Quarterly Journal of Economics, 128(2), pp. 531-580.

Denk, O. (2016), "How Do Product Market Regulations Affect Workers? Evidence From the Network Industries", OECD Economics Department Working Papers, No. 1349, OECD Publishing, Paris.

De Serres, A. and F. Murtin (2013), "Do Policies that Reduce Unemployment Raise its Volatility?", OECD Economics Department Working Papers, No. 1020, OECD Publishing, Paris.

De Serres, A. and F. Murtin (2014), "Unemployment at Risk: The Policy Determinants of Labour Market Exposure to Economic Shocks", Economic Policy, 29(80), pp. 603-637.

Disney, R., J. Haskel and Y. Heden (2003), "Restructuring and Productivity Growth in UK Manufacturing", Economic Journal, 113(489), pp. 666-694.

Duval, R. (2008), "Is There a Role for Macroeconomic Policy in Fostering Structural Reforms? Panel Evidence from OECD Countries over the Past Two Decades", European Journal of Political Economy, 24(2), pp. 491-502.

Frey, B. and A. Stutzer (2000), "Happiness, Economy and Institutions", Economic Journal, 110(446), pp. 918-938.

Gal, P. and A. Theising (2015), "The Macroeconomic Impact of Structural Policies on Labour Market Outcomes in OECD countries", OECD Economics Department Working Papers, No. 1271, OECD Publishing, Paris.

Garda, P. (2016), "The Ins and Outs of Employment in 25 OECD Countries", OECD Economics Department Working Papers, No. 1350, OECD Publishing, Paris.

Gómez Salvador, R., J. Messina and G. Vallanti (2004), "Gross Job Flows and Institutions in Europe", Labour Economics, 11(4), pp. 469-485. 
Hijzen, A. and B. Menyhert (2015), "Measuring Labour Market Security and Assessing Its Implications for Individual Well-Being", OECD Social, Employment and Migration Working Papers, No. 175, OECD Publishing, Paris.

Høj, J., V. Galasso, G. Nicoletti and T.-T. Dang (2006), “An Empirical Investigation of Political Economy Factors Behind Structural Reforms in OECD Countries", OECD Economic Studies, 42, pp. 87-136, OECD Publishing, Paris.

Jackman, R., R. Layard and S. Nickell (1996), “Combating Unemployment: Is Flexibility Enough?”, CEP Discussion Papers, No. 293.

Kenworthy, L. (2001), "Wage-Setting Institutions: A Survey and Assessment”, World Politics, 54(1), pp. 57-98.

Marinescu, I. (2009), "Job Security Legislation and Job Duration: Evidence from the UK", Journal of Labor Economics, 27(3), pp. 465-485.

Martin, J. (2014), "Activation and Active Labour Market Policies in OECD Countries: Stylised Facts and Evidence on their Effectiveness", IZA Policy Papers, No. 84.

Micco, A. and C. Pagés (2008), "The Economic Effects of Employment Protection: Evidence from International Industry-Level Data", IZA Discussion Papers, No. 2433.

Murtin, F. and A. de Serres (2014), "How Do Policies Affect the Exit Rate out of Unemployment? Disentangling Job Creation from Labour Market Frictions", Labour, 28(2), pp.190-208.

Nicoletti, G. and S. Scarpetta (2005), "Product Market Reforms and Employment in OECD Countries", OECD Economics Department Working Papers, No. 472, OECD Publishing, Paris.

OECD (2007), "More Jobs but Less Productive? The Impact of Labour Market Policies on Productivity", Chapter 2 in OECD Employment Outlook 2007, OECD Publishing, Paris.

OECD (2010), "Institutional and Policy Determinants of Labour Market Flows", Chapter 3 in $O E C D$ Employment Outlook 2010, OECD Publishing, Paris.

OECD (2011), "Earnings Volatility: Causes and Consequences", Chapter 3 in OECD Employment Outlook 2011, OECD Publishing, Paris.

OECD (2013), "Protecting Jobs, Enhancing Flexibility: A New Look at Employment Protection Legislation”, Chapter 2 in OECD Employment Outlook 2013, OECD Publishing, Paris.

OECD (2016), "Short-Term Effects of Structural Reforms: Pain Before the Gain?", Chapter 3 in OECD Employment Outlook 2016, OECD Publishing, Paris.

Olley, S. and A. Pakes (1996), "The Dynamics of Productivity in the Telecommunications Equipment Industry", Econometrica, 64(6), pp. 263-297.

Pareliussen, J. (2014), "Overcoming Vulnerability of Unemployment Insurance Schemes", OECD Economics Department Working Papers, No. 1131, OECD Publishing, Paris. 
Schiantarelli, F. (2010), "Product Market Regulation and Macroeconomic Performance: A Review of Cross-Country Evidence", in: N. Loayza and L. Serven (eds.), The Microeconomic Underpinning of Growth, The World Bank.

Visser, J. (2015), "Data Base on Institutional Characteristics of Trade Unions, Wage Setting, State Intervention and Social Pacts, 1960-2014 (ICTWSS)", Version 5.0, Amsterdam Institute for Advanced Labour Studies, AIAS, Amsterdam, October. 


\section{APPENDIX A1. ROBUSTNESS CHECKS}

72. As robustness checks, the control variables in the baseline estimations of Table 4 are extended to include other covariates, which are often included in country-level employment/unemployment regressions (Bassanini and Duval, 2009; Gal and Theising, 2015). The reason to have as baseline estimation the one in Table 4 is that including other policy variables reduces the sample by $30 \%$. A $30 \%$ reduction in sample size is a more serious drawback in this paper than the country-level statistics used by Bassanini and Duval (2009) and Gal and Theising (2015), because the micro-level databases cover fewer countries and years.

73. Table A1 shows the results for the probability of becoming jobless (Panel A) and the probability of finding a job (Panel B). The first two columns replicate the results in Table 4 for comparability reasons. Columns 3 and 4 show the results including EPL and ETCR or PMR in this restricted sample. Finally, Columns 5 and 6 include all policy variables.

74. Results are robust to including other policy variables. The main results from the previous analysis is that making product markets more competitive increases the probability of finding a job, while the probability of becoming jobless remains unchanged. This conclusion holds when adding other policies. The only exception is for PMR, where a reduction in product market regulation would increase the probability of becoming jobless. However, this shift is related to the reduction in the sample size, more than to the addition of other policy variables.

75. Finally, deregulation of labour markets seems to have no significant association with transitions in and out of employment. In some cases, EPL-R or EPL-T are significant to explain one of the two types of transitions, but these results are not robust across specifications and more related to the sample reduction than to the addition of policy variables. 
Table A1.1. Adding other policy variables to the baseline estimation

\begin{tabular}{|c|c|c|c|c|c|c|}
\hline \multicolumn{7}{|c|}{ A. Transition employment-joblessness } \\
\hline & \multicolumn{2}{|c|}{ Baseline } & \multicolumn{2}{|c|}{ Restricting the sample } & \multicolumn{2}{|c|}{ Adding policies } \\
\hline EPL-R & $\begin{array}{l}-0.008 \\
(0.013)\end{array}$ & $\begin{array}{l}-0.013 \\
(0.012)\end{array}$ & $\begin{array}{c}-0.076^{\star *} \\
(0.031)\end{array}$ & $\begin{array}{l}-0.028 \\
(0.019)\end{array}$ & $\begin{array}{l}-0.057^{*} \\
(0.030)\end{array}$ & $\begin{array}{l}-0.005 \\
(0.016)\end{array}$ \\
\hline EPL-T & $\begin{array}{l}-0.002 \\
(0.004)\end{array}$ & $\begin{array}{l}-0.001 \\
(0.003)\end{array}$ & $\begin{array}{c}0.007 \\
(0.011)\end{array}$ & $\begin{array}{l}0.007^{\star} \\
(0.004)\end{array}$ & $\begin{array}{c}0.004 \\
(0.011)\end{array}$ & $\begin{array}{c}0.008^{* * *} \\
(0.003)\end{array}$ \\
\hline PMR & $\begin{array}{l}-0.019 \\
(0.013)\end{array}$ & & $\begin{array}{l}-0.053^{\star *} \\
(0.021)\end{array}$ & & $\begin{array}{l}-0.040^{*} \\
(0.020)\end{array}$ & \\
\hline ETCR & & $\begin{array}{l}-0.002 \\
(0.005)\end{array}$ & & $\begin{array}{l}0.010^{*} \\
(0.006)\end{array}$ & & $\begin{array}{c}0.006 \\
(0.006)\end{array}$ \\
\hline GRR & & & & & $\begin{array}{l}0.002^{\star * \star} \\
(0.001)\end{array}$ & $\begin{array}{c}0.003^{* * *} \\
(0.001)\end{array}$ \\
\hline ALMP & & & & & $\begin{array}{l}-0.000 \\
(0.000)\end{array}$ & $\begin{array}{c}0.000 \\
(0.000)\end{array}$ \\
\hline Tax wedge & & & & & $\begin{array}{l}-0.001 \\
(0.001)\end{array}$ & $\begin{array}{l}-0.001 \\
(0.001)\end{array}$ \\
\hline Coverage & & & & & $\begin{array}{c}0.001 \\
(0.001)\end{array}$ & $\begin{array}{l}0.001^{* * *} \\
(0.001)\end{array}$ \\
\hline $\begin{array}{l}\text { Observations } \\
\mathrm{N} \text { of clusters }\end{array}$ & $\begin{array}{c}932202 \\
224\end{array}$ & $\begin{array}{c}1088520 \\
263\end{array}$ & $\begin{array}{c}626896 \\
151\end{array}$ & $\begin{array}{c}759958 \\
187\end{array}$ & $\begin{array}{c}626896 \\
151\end{array}$ & $\begin{array}{c}759958 \\
187\end{array}$ \\
\hline R-squared & 0.039 & 0.038 & 0.037 & 0.037 & 0.038 & 0.037 \\
\hline \multicolumn{7}{|c|}{ B. Trabsition joblessness-employment } \\
\hline & \multicolumn{2}{|c|}{ Baseline } & Restricting & e sample & \multicolumn{2}{|c|}{ Adding policies } \\
\hline EPL-R & $\begin{array}{c}0.027 \\
(0.026)\end{array}$ & $\begin{array}{c}0.009 \\
(0.019)\end{array}$ & $\begin{array}{c}-0.132^{\star \star \star} \\
(0.046)\end{array}$ & $\begin{array}{l}-0.028 \\
(0.020)\end{array}$ & $\begin{array}{c}-0.140^{\star \star \star} \\
(0.048)\end{array}$ & $\begin{array}{c}-0.006 \\
(0.019)\end{array}$ \\
\hline EPL-T & $\begin{array}{l}-0.011 \\
(0.009)\end{array}$ & $\begin{array}{c}0.003 \\
(0.006)\end{array}$ & $\begin{array}{l}-0.027 \\
(0.020)\end{array}$ & $\begin{array}{c}0.001 \\
(0.007)\end{array}$ & $\begin{array}{l}-0.035 \\
(0.021)\end{array}$ & $\begin{array}{c}0.002 \\
(0.006)\end{array}$ \\
\hline PMR & $\begin{array}{l}-0.064^{*} \\
(0.035)\end{array}$ & & $\begin{array}{l}-0.181^{* * *} \\
(0.047)\end{array}$ & & $\begin{array}{c}-0.166^{* * *} \\
(0.045)\end{array}$ & \\
\hline ETCR & & $\begin{array}{c}-0.034^{* \star *} \\
(0.010)\end{array}$ & & $\begin{array}{c}-0.044^{\star * *} \\
(0.012)\end{array}$ & & $\begin{array}{c}-0.052^{\star * *} \\
(0.014)\end{array}$ \\
\hline GRR & & & & & $\begin{array}{c}0.001 \\
(0.002)\end{array}$ & $\begin{array}{c}0.002 \\
(0.002)\end{array}$ \\
\hline ALMP & & & & & $\begin{array}{l}-0.000 \\
(0.001)\end{array}$ & $\begin{array}{c}0.001 \\
(0.001)\end{array}$ \\
\hline Tax wedge & & & & & $\begin{array}{c}0.002 \\
(0.002)\end{array}$ & $\begin{array}{l}-0.003 \\
(0.002)\end{array}$ \\
\hline Coverage & & & & & $\begin{array}{c}0.001 \\
(0.001) \\
\end{array}$ & $\begin{array}{c}0.001 \\
(0.001) \\
\end{array}$ \\
\hline $\begin{array}{l}\text { Observations } \\
\mathrm{N} \text { of clusters }\end{array}$ & $\begin{array}{c}336457 \\
224\end{array}$ & $\begin{array}{c}398997 \\
263\end{array}$ & $\begin{array}{c}226021 \\
151\end{array}$ & $\begin{array}{c}276768 \\
187\end{array}$ & $\begin{array}{c}226021 \\
151\end{array}$ & $\begin{array}{c}276768 \\
187\end{array}$ \\
\hline R-squared & 0.196 & 0.196 & 0.193 & 0.193 & 0.193 & 0.193 \\
\hline
\end{tabular}

Note: Joblessness refers to unemployment or being out of the labour force. All regressions are estimated by OLS, assuming a linear generalised probability model. They include age, age squared, education level, average monthly labour income quartile, gender, output gap, government employment, population growth, country and year fixed effects. EPL is the OECD index of the strictness of Employment Protection Legislation. R stands for regular contracts, T for temporary ones. ETCR is the OECD index of Energy, Transport and Communication Regulation. PMR is the OECD Product Market Regulation index. GRR is the Gross Replacement Rate which expresses gross unemployment benefit levels as a percentage of previous gross earnings. ALMP (Active Labour Market Policies) is spending on active labour market policies per unemployed as a percentage of GDP per capita. Tax wedge for a one earner married couple with two children at $100 \%$ of the average wage. Coverage is the proportion of employees covered by collective bargaining over all wage earners. ${ }^{* *}$ indicates significance at the $1 \%$ level, ${ }^{* \star}$ at the $5 \%$ level and ${ }^{*}$ at the $10 \%$ level. The regressions are run on micro-level data covering 26 OECD countries over 1994-2012 (see Table 1 for details on the sample coverage). Standard errors are clustered at the country-year level.

Source: Authors' calculations using ECHP; EU-SILC; HILDA; SHP; SOEP; OECD Product Market Regulation database; OECD Economic Outlook database, ICTWSS. 


\section{APPENDIX A2. ESTIMATION RESULTS FOR JOB-TO-JOB FLOWS}

Table A2.1. Regression results for job-to-job transitions

\begin{tabular}{|c|c|c|c|c|c|c|}
\hline & (1) & (2) & (3) & (4) & (5) & (6) \\
\hline EPL-R & $\begin{array}{c}0.003 \\
(0.013)\end{array}$ & & & & $\begin{array}{c}0.004 \\
(0.017)\end{array}$ & $\begin{array}{l}-0.001 \\
(0.012)\end{array}$ \\
\hline EPL-T & & $\begin{array}{l}-0.006 \\
(0.005)\end{array}$ & & & $\begin{array}{l}-0.002 \\
(0.011)\end{array}$ & $\begin{array}{l}-0.008^{*} \\
(0.004)\end{array}$ \\
\hline PMR & & & $\begin{array}{l}-0.021 \\
(0.055)\end{array}$ & & $\begin{array}{l}-0.016 \\
(0.054)\end{array}$ & \\
\hline ETCR & & & & $\begin{array}{c}0.000 \\
(0.016)\end{array}$ & & $\begin{array}{c}0.006 \\
(0.017)\end{array}$ \\
\hline $\begin{array}{l}\mathrm{N} \text { of obs } \\
\mathrm{N} \text { of clusters } \\
\mathrm{R}^{2}\end{array}$ & $\begin{array}{c}843255 \\
263 \\
0.024\end{array}$ & $\begin{array}{c}843255 \\
263 \\
0.024\end{array}$ & $\begin{array}{c}715317 \\
224 \\
0.025\end{array}$ & $\begin{array}{c}862625 \\
271 \\
0.025\end{array}$ & $\begin{array}{c}714577 \\
224 \\
0.025\end{array}$ & $\begin{array}{c}843255 \\
263 \\
0.025\end{array}$ \\
\hline
\end{tabular}

Note: Job-to-job transitions are defined as changing employers without experiencing a period out of employment. All regressions are estimated by OLS, assuming a linear generalised probability model. They include age, age squared, education level, average monthly labour income quartile, gender, output gap, government employment, population growth, country and year fixed effects. EPL is the OECD index of Employment Protection Legislation. R stands for regular contracts, T for temporary ones. ETCR is the OECD index of Energy, Transport and Communication Regulation. PMR is the OECD Product Market Regulation index. ${ }^{* * *}$ indicates significance at the $1 \%$ level, ${ }^{* *}$ at the $5 \%$ level and ${ }^{*}$ at the $10 \%$ level. The regressions are run on micro-level data covering 26 OECD countries over 1994-2012 (see Table 1 for details on the sample coverage). Standard errors are clustered at the country-year level.

Source: Authors' calculations using ECHP; EU-SILC; HILDA; SHP; SOEP; OECD Employment database; OECD Product Market Regulation database; OECD Economic Outlook database. 


\section{APPENDIX A3. ACRONYMS}

$\begin{array}{ll}\text { ALMP } & \text { Active labour market policies } \\ \text { BHPS } & \text { British Household Panel Survey } \\ \text { ECHP } & \text { European Community Household Panel } \\ \text { ETCR } & \text { Energy, transport and communication regulation } \\ \text { EPL } & \text { Employment protection legislation } \\ \text { EPL-R } & \text { Employment protection legislation for regular contracts } \\ \text { EPL-T } & \text { Employment protection legislation for temporary contracts } \\ \text { HILDA } & \text { Household, Income and Labour Dynamics in Australia } \\ \text { ICTWWS } & \begin{array}{l}\text { Database on Institutional Characteristics of Trade Union, Wage Setting, } \\ \text { State Intervention and Social Pacts }\end{array} \\ \text { PES } & \text { Public employment services } \\ \text { PMR } & \text { Product market regulation } \\ \text { SES } & \text { Structure of Earnings Survey } \\ \text { SHP } & \text { Swiss Household Panel } \\ \text { SILC } & \text { Survey of Income and Living Conditions } \\ \text { SOEP } & \text { Socio-Economic Panel }\end{array}$

